JOURNAL OF FLOW CHEMISTRY (ISSN: 2062-249X) (eISSN: 2063-0212) 4: (3) pp. 125134. (2014)

DOI: 10.1556/JFC-D-14-00011 


\title{
Lipase-catalyzed kinetic resolution of 1-(2-hydroxycyclohexyl)indoles in batch and continuous-flow systems
}

\author{
Péter Falus $^{1}$, Zoltán Boros ${ }^{1,2}$, Péter Kovács ${ }^{3}$, László Poppe ${ }^{1,2^{*}}$, József Nagy ${ }^{1,2^{*}}$ \\ ${ }^{1}$ Department of Organic Chemistry and Technology, Budapest University of Technology and \\ Economics, H-1111 Budapest, Müegyetem rkp. 3., Hungary \\ ${ }^{2}$ SynBiocat Ltd., H-1173 Budapest, Lázár deák u. 4/1., Hungary \\ ${ }^{3}$ Research Centre for Natural Sciences, Institute of Organic Chemistry, Hungarian Academy \\ of Sciences, H-1117 Budapest, Magyar tudósok körútja 2., Hungary
}

\begin{abstract}
The lipase catalysed kinetic resolution of three trans-1-(2-hydroxycyclohexyl)-indoles in both batch and continuous-flow systems is reported. Ring opening of cyclohexene oxide by the corresponding indole followed by enzymatic acylation with vinyl acetate resulted in novel, highly enantioenriched indole-substituted cyclohexanols and cyclohexyl acetates. The effect of the temperature on enantiomeric ratio $(E)$ and productivity (specific reaction rate, $r_{\text {flow }}$ ) in the continuous-flow mode acylation was studied at analytical scale in the $0-70^{\circ} \mathrm{C}$ range. Preparative scale kinetic resolution of the three indole derivatives was performed in mixed continuous- and recirculation-flow mode resulting in almost complete conversion and good to excellent enantiomeric purity of the products.
\end{abstract}

Keywords: Lipase, heterocyclic secondary alcohol, kinetic resolution, continuous-flow biotransformation, enantiomer selectivity, temperature effect

\section{Introduction}

Indole derivatives are important as natural compounds and utilized not only in the pharmaceutical industry but also used in agrochemicals (e.g. fungicides, herbicides), in dietary supplements and nutraceuticals, colorants industry or fragrance industry. ${ }^{1,2}$ Substituted

\footnotetext{
* Corresponding authors. Department of Organic Chemistry and Technology, Budapest University of Technology and Economics, H-1111 Budapest, Müegyetem rkp. 3., Hungary. Tel: +36 1463 3299; fax: +36 14633697

E-mail addresses: jnagy@mail.bme.hu (J. Nagy), poppe@mail.bme.hu (L. Poppe)
} 
indole skeleton is a prevalent building block of numerous pharmaceutical agents. One of the reasons which make indole ring quite indispensable is the wide range of biological effects: e.g. the amino-acid tryptophan, the hormones serotonin $^{3}$ and melatonin ${ }^{4}$, the psychotropic drugs LSD, ${ }^{5}$ bufotenine and psilobycin ${ }^{6}$ and the antitumor agent vinblastine. ${ }^{7,8}$

Ring opening of epoxides with indole derivatives under neutral or basic conditions follows an $\mathrm{S}_{\mathrm{N}} 2$ mechanism and provide trans-1,2-disubstituted products. ${ }^{9}$ These reactions usually require a strong base or acid, ${ }^{10}$ high temperature ${ }^{11}$ or high pressure. ${ }^{12}$ Recently, epoxy ring opening under microwave condition ${ }^{13,14}$ or in continuous-flow reactor ${ }^{15}$ have been reported.

Due to the ever growing need of the pharmaceutical and fine chemicals industries for enantiomerically pure compounds, the armoury of novel stereoselective synthetic methods is continuously expanding. The use of biocatalysts for these purposes grows with this expansion $^{16-19}$ since biocatalysis often requires milder conditions in stereoselective reaction than chemocatalysis. Hydrolases, especially lipases are among the most often used enzymes for synthetic purposes. $^{20}$ Lipases have been used for numerous stereoselective biotransformations $^{21-26}$ such as kinetic resolution $(\mathrm{KR})^{20,27}$, deracemisation and dynamic kinetic resolution $(\mathrm{DKR})^{30}$ due to their high regio-, chemo- and enantioselectivity, high stability, compatibility of organic solvents, wide substrate range, and because they do not need co-factors. Lipases - either in their native form or tailored by genetic engineering - are ideally suited for industrial applications, ${ }^{17,28}$ preferably in their immobilised forms to enable recycling. Alcohols and amines are the most thoroughly investigated substrates in KR and DKR. ${ }^{29-38}$ The production of chiral alcohols brought in 2002 more than 7 billion dollars in revenues worldwide and this was forecasted to be 14.9 billion dollars by the year $2009 .{ }^{39}$

Although a tremendous number of biocatalytic reactions have been studied, ${ }^{16-18,20-26}$ the operational parameters reported for most of them seem to be rather suboptimal. Therefore, there is still much room for optimization promoting thereby faster transfer to an industrial scale. Even today, most of biosynthetic operations are performed as a fixed, batch based single step procedure. Although continuous processes offer several advantages - such as facile automation, reproducibility and safety - the benefits of the flow-through approach ${ }^{40-45}$ have not been fully exploited so far.

Because immobilized biocatalysts are recyclable, storable and easy to handle, immobilization is an important trend in biotechnology. ${ }^{46-51}$ Selectivity, specificity, catalytic activity and enzyme stability are key factors affecting the efficiency of biocatalysts. ${ }^{16-18,20-26}$ Immobilization can often improve these key properties ${ }^{46-51}$ and also enabling the use of biocatalysts under continuous-flow conditions. ${ }^{19}$ 
Among the factors influencing selectivity, catalytic activity and stability of the biocatalysts under continuous-flow conditions, temperature effects are the most important. In enzymecatalysed reactions, increasing temperature generally decreases selectivity. ${ }^{52-62}$ In a few studies, however, enhanced selectivity with increasing temperature, ${ }^{63,64}$ or a maximum of enantioselectivity at a certain temperature, ${ }^{38,65}$ or even indifference to temperature was found. ${ }^{66}$ In most of the quoted examples, the enzyme-catalysed reactions were carried out in batch mode (in stirred or shaken flasks) and only a few studies on the temperature effects on lipase-catalysed KRs were performed in continuous-flow mode so far. ${ }^{19,38,65}$

Herein the synthesis and lipase-catalysed kinetic resolutions of racemic 1-(2hydroxycyclohexyl)indoles $(\mathrm{rac}-\mathbf{2 a}-\mathbf{c})$ are reported in both batch and continuous-flow systems (Scheme 1). According to our best knowledge, these are the first KRs of the already known (rac-2a) and of the novel trans-1-(2-hydroxycyclohexyl)indoles (rac-2b and rac-2c). The effect of temperature on enantiomer selectivity was also investigated under continuousflow conditions.
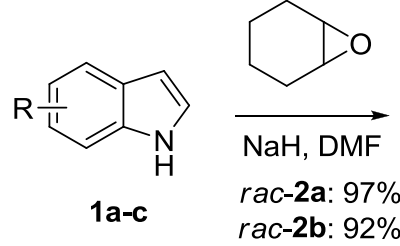

rac-2c: $98 \%$

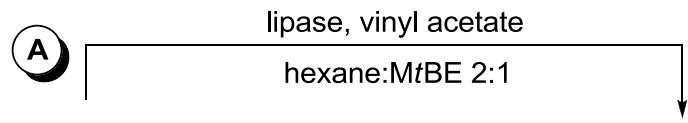

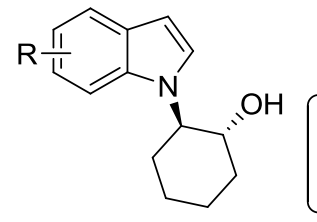

trans-rac-2a-c

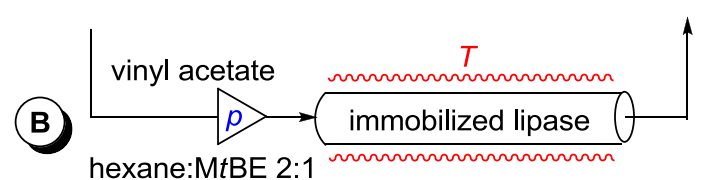

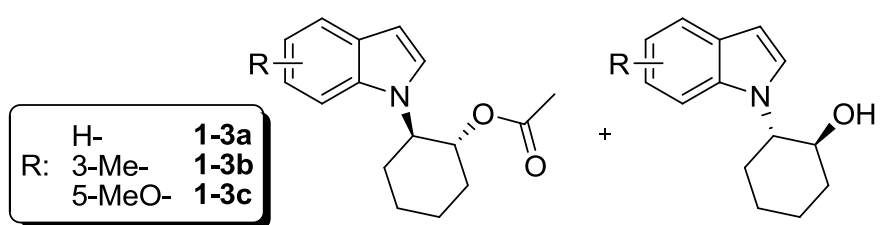

$(R, R)-3 \mathbf{a}-\mathbf{c}$

$(S, S)-\mathbf{2 a - c}$

Scheme 1. Synthesis and kinetic resolution of secondary alcohols ( $r a c-2 a-c)$ in batch (A) and in continuous-flow mode (B)

\section{Results and Discussion}

For this study, three indole-substituted cyclohexanols (rac-2a-c) were synthesised by a slight modification of the process described for the preparation of rac-2a (Scheme 1) ${ }^{67}$ i.e. the ring opening of cyclohexene oxide with the corresponding indole derivate $(\mathbf{1 a}-\mathbf{c})$ using $\mathrm{NaH}$ (1 equiv.) in dry DMF. The indoles (1b and 1c) bearing slightly electron donating substituents showed similar reactivity as the unsubstituted indole (1a) providing the new indolesubstituted trans-cyclohexanols ( $r a c-2 \mathbf{b}$ and $r a c-2 \mathbf{c})$ in excellent yields.

\subsection{Kinetic resolution of secondary alcohols $(\mathrm{rac}-2 \mathrm{a}-\mathrm{c})$ in batch mode}


KRs of the indole-substituted secondary alcohols (rac-2a-c) were carried out with 23 different lipases by acylation with vinyl acetate (Table 1).

Table 1. Lipase-catalysed kinetic resolution of secondary alcohols (rac-2a-c) by acylation with vinyl acetate in batch mode $\left(30^{\circ} \mathrm{C}\right.$, shake flask).

\begin{tabular}{|c|c|c|c|c|c|c|}
\hline Entry & Substrate & Enzyme & $c(\%)^{a}$ & $e e_{(R, R)-\mathbf{3 a}}(\%)^{b}$ & $E^{c}$ & $r_{\text {batch }}\left(\mu \mathrm{mol} \mathrm{g} \mathrm{g}^{-1} \mathrm{~h}^{-1}\right)$ \\
\hline \multicolumn{7}{|c|}{ Panel $\mathrm{A}^{d}$} \\
\hline 1 & $r a c-\mathbf{2 a}$ & CaLB N435 & 49.9 & >99.9 & $» 200$ & 32.6 \\
\hline 2 & $r a c-\mathbf{2 a}$ & Lipobond PS & 47.2 & >99.9 & $» 200$ & 30.8 \\
\hline 3 & $r a c-\mathbf{2 a}$ & Lipozyme TLIM & 40.2 & >99.9 & $» 200$ & 26.2 \\
\hline 4 & $r a c-\mathbf{2 a}$ & Lipozyme MmL & 38.7 & >99.9 & $» 200$ & 25.3 \\
\hline 5 & $r a c-\mathbf{2 a}$ & Amano AK & 37.0 & >99.9 & $» 200$ & 24.1 \\
\hline 6 & $r a c-\mathbf{2 a}$ & CaLA G250P & 25.1 & 99.8 & $» 200$ & 16.4 \\
\hline 7 & $r a c-\mathbf{2 a}$ & CaLA T2-150 & 14.7 & 99.6 & $» 200$ & 9.6 \\
\hline 8 & $r a c-\mathbf{2 a}$ & MpL G250P & 13.9 & 99.9 & $» 200$ & 9.0 \\
\hline 9 & $r a c-\mathbf{2 a}$ & MpL G250O & 11.1 & 99.9 & $» 200$ & 7.2 \\
\hline 10 & $r a c-\mathbf{2 a}$ & CaLB G250P & 9.4 & 99.9 & $» 200$ & 6.2 \\
\hline 11 & $r a c-\mathbf{2 a}$ & PaL G250P & 8.6 & 99.8 & $» 200$ & 5.6 \\
\hline \multicolumn{7}{|c|}{ Panel B ${ }^{e}$} \\
\hline 12 & $r a c-\mathbf{2 b}$ & CaLB N435 & 41.2 & >99.9 & $\gg 200$ & 37.6 \\
\hline 13 & $r a c-\mathbf{2 b}$ & Lipobond PS & 27.7 & >99.9 & $\gg 200$ & 25.0 \\
\hline 14 & $r a c-\mathbf{2 b}$ & Lipozyme TLIM & 27.4 & >99.9 & $» 200$ & 25.0 \\
\hline 15 & $r a c-\mathbf{2 b}$ & Lipozyme MmL & 24.1 & >99.9 & $\gg 200$ & 21.7 \\
\hline 16 & $r a c-\mathbf{2 b}$ & CaLB G250P & 12.9 & 99.9 & $» 200$ & 11.9 \\
\hline 17 & $r a c-\mathbf{2 b}$ & Amano AK & 9.0 & 99.9 & $\gg 200$ & 8.1 \\
\hline 18 & $r a c-\mathbf{2 b}$ & Amano M & 6.5 & 99.9 & $» 200$ & 5.9 \\
\hline 19 & $r a c-\mathbf{2 b}$ & Amano PS & 5.5 & 99.8 & $\gg 200$ & 5.0 \\
\hline \multicolumn{7}{|c|}{ Panel C } \\
\hline 20 & $r a c-2 c$ & Lipozyme TLIM & 44.9 & $>99.9$ & $» 200$ & 38.6 \\
\hline 21 & $r a c-2 c$ & CaLB N435 & 38.7 & $>99.9$ & $\gg 200$ & 33.0 \\
\hline 22 & $r a c-2 c$ & Lipozyme MmL & 34.4 & >99.9 & $» 200$ & 29.1 \\
\hline 23 & $r a c-2 c$ & Lipobond PS & 33.5 & >99.9 & $» 200$ & 28.5 \\
\hline 24 & $r a c-2 c$ & Amano AK & 27.0 & 99.9 & $» 200$ & 22.8 \\
\hline 25 & $r a c-2 c$ & CaLB G250P & 13.7 & 99.9 & $» 200$ & 11.7 \\
\hline 26 & $r a c-2 c$ & CaLA G250P & 10.6 & 99.9 & $» 200$ & 9.0 \\
\hline 27 & $r a c-\mathbf{2 c}$ & $\mathrm{CrL}$ & 7.3 & 99.9 & »200 & 6.2 \\
\hline 28 & $r a c-2 c$ & Amano PS & 7.2 & 99.8 & $» 200$ & 6.1 \\
\hline 29 & $r a c-2 c$ & CaLA T2-150 & 6.9 & 99.8 & $» 200$ & 5.9 \\
\hline
\end{tabular}

${ }^{a}$ Results are shown only for reactions with $c>5 \%$.

${ }^{b}$ Enantiomeric excess of ester $\left(e e_{(R, R)-3 \mathrm{a}-\mathrm{c}}\right)$ was determined by chiral GC.

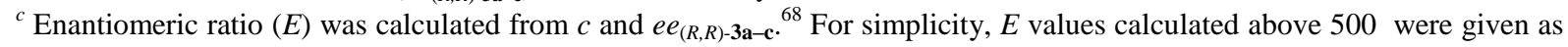
$\gg 200$.

${ }^{d}$ Reaction time $72 \mathrm{~h}$.

${ }^{e}$ Reaction time $48 \mathrm{~h}$.

The KRs were performed in hexane-tert-butyl methyl ether $(2: 1)$ at $30^{\circ} \mathrm{C}$ using various forms of the lipases (such as lyophilised powder, adsorbed on surface-modified silica gel, 
acrylic or ion-exchange resins, as well as covalently attached to acrylic resin). In the KR of the unsubstituted indole derivative $r a c-2 a$, excellent enantiomer selectivity $(E \gg 200)$ was observed with most of the biocatalysts (Table 1, Panel A). Enantiomeric excess of the product $(R, R)$-3a was predominantly at least $99.9 \%$. Moreover, this could be realised at conversions of $35 \%$ or above with five lipase preparations while KR was almost complete (nearly 50\% conversion) with CaLB N435 or Lipobond PS. Although in the case of CaLA or CaLB significant differences were found in selectivity and activity due to the nature of the hydrophobic grafting of the silica gel supports, ${ }^{69}$ in the case of MpL no significant differences were observed between the forms adsorbed onto phenyl- and octyl-grafted silica gels (Entries 8 and 9 , respectively).

In the case of several other lipases, however, remarkable variations were found when the same lipase was immobilised by different methods. Such phenomena were observed when CaLA was adsorbed either on phenyl-grafted silica gel or attached covalently to porous polymethacrylate beads (Entries 6 and 7, respectively) or when CaLB was adsorbed on acrylic resin or on phenyl modified silica gel (Entries 1 and 10, respectively). In the case of CaLA, the phenyl silica-adsorbed form showed both higher activity and selectivity (Entry 6) than the other form (Entry 7). The high enantiomer selectivity of CaLA with rac-2a $(E » 200)$ is also noteworthy, because in other KRs of various secondary alcohols this lipase was not particularly selective. ${ }^{36,69,70}$ With CaLB, adsorbed on acrylic resin (Entry 1) was much more active but similarly selective than when adsorbed onto phenyl silica (Entry 10). Surprisingly, the lipase from Burkholderia cepacia exhibited no activity as lyophilised powder (Amano PS) or when adsorbed on octyl-grafted silica gel (data not shown in Table 1), whereas excellent enantiomeric excess values and conversions were observed when it was covalently attached to acrylic resin (Entry 2).

The KRs of rac-2b (Table 1, Panel B) proceeded quite similarly to those of rac-2a. The best selectivity and activity was achieved with the same four biocatalysts (CaLB N435, Lipobond PS, Lipozyme TLIM and Lipozyme MmL; Entries 12-15) as with of rac-2a. Although, each biocatalysts showed somewhat lower activity compared to the series with rac2a, excellent enantiomer selectivity was maintained ( $E » 200$; Entries 12-15).

Amano AK proved to be much less active with $\mathrm{rac}-\mathbf{2} \mathbf{b}(c=9.0 \%$ in Entry 5) than with rac2a $(c=37.0 \%$ in Entry 17$)$, but its high selectivity $\left(E \gg 200\right.$ and $\left.e e_{(R, R)-3 \mathbf{a}} \geq 99.9 \%\right)$ was retained. Surprisingly, CaLA and MpL which were active on rac-2a (Entries 6-9) did not exhibit any notable activity on $\mathbf{r a c}-\mathbf{2 b}$. On the other hand, the lyophilised lipases Amano M and Amano PS which were apparently inactive with rac-2a catalysed the acylation of rac-2b (Entries 18 
and 19). These results indicated that a substituent of moderate size at position 3 of the indole moiety in $\mathbf{2 b}$ did not cause much variation among the various lipases concerning the relative binding orientation of the enantiomers of $\mathbf{2} \mathbf{b}$ as compared to those of $\mathbf{2} \mathbf{a}$ but influenced only their binding ability.

The KR results with $r a c-2 c$ are shown in Table 1 (Panel C). The fact that Lipozyme TLIM was significantly more active (Entry 20) than CaLB N435 (Entry 21) indicated that 5-MeOsubstitution of the indole moiety requires a quite different steric environment within the active site than the one necessary for the two previously discussed 2-(1-indolyl)cyclohexanols ( $\mathrm{rac}$ 2a-b). In the case of $\mathrm{CrL}$, the different steric requirement for efficient catalysis in the KR of rac-2c was also obvious, because this lipase was active only in the $\mathrm{KR}$ of the 5-MeOsubstituted substrate. It showed moderate activity and excellent enantiomer selectivity (Entry 27) but was apparently inactive with the other two cyclohexanols ( $r a c-2 a-b)$. Although CaLB was not the most active biocatalyst in KR of rac-2c, but demonstrated a high degree of enantiomer selectivity (Entries 21 and 25). This applied to both forms of CaLA in KRs of rac2c (Entries 26 and 29). Similarly, excellent selectivities could be achieved with Lipozyme MmL, Lipobond PS, Amano AK and Amano PS at lower conversions (Entries 22, 23, 24 and 28 , respectively).

\subsection{Continuous-flow kinetic resolution of secondary alcohols $(\mathrm{rac}-\mathbf{2 a}-\mathrm{c})$}

KRs in continuous-flow mode were carried out in a multicolumn reactor system (Figure 1) assembled within a multicolumn metal block reactor (Figure 1B), an external cooling-heating thermostat, a temperature control unit and an isocratic HPLC pump. The reactions in continuous-flow mode (Figure 1C) were performed in stainless steel packed bed CatCart ${ }^{\mathrm{TM}}$ columns filled with the proper biocatalyst. 

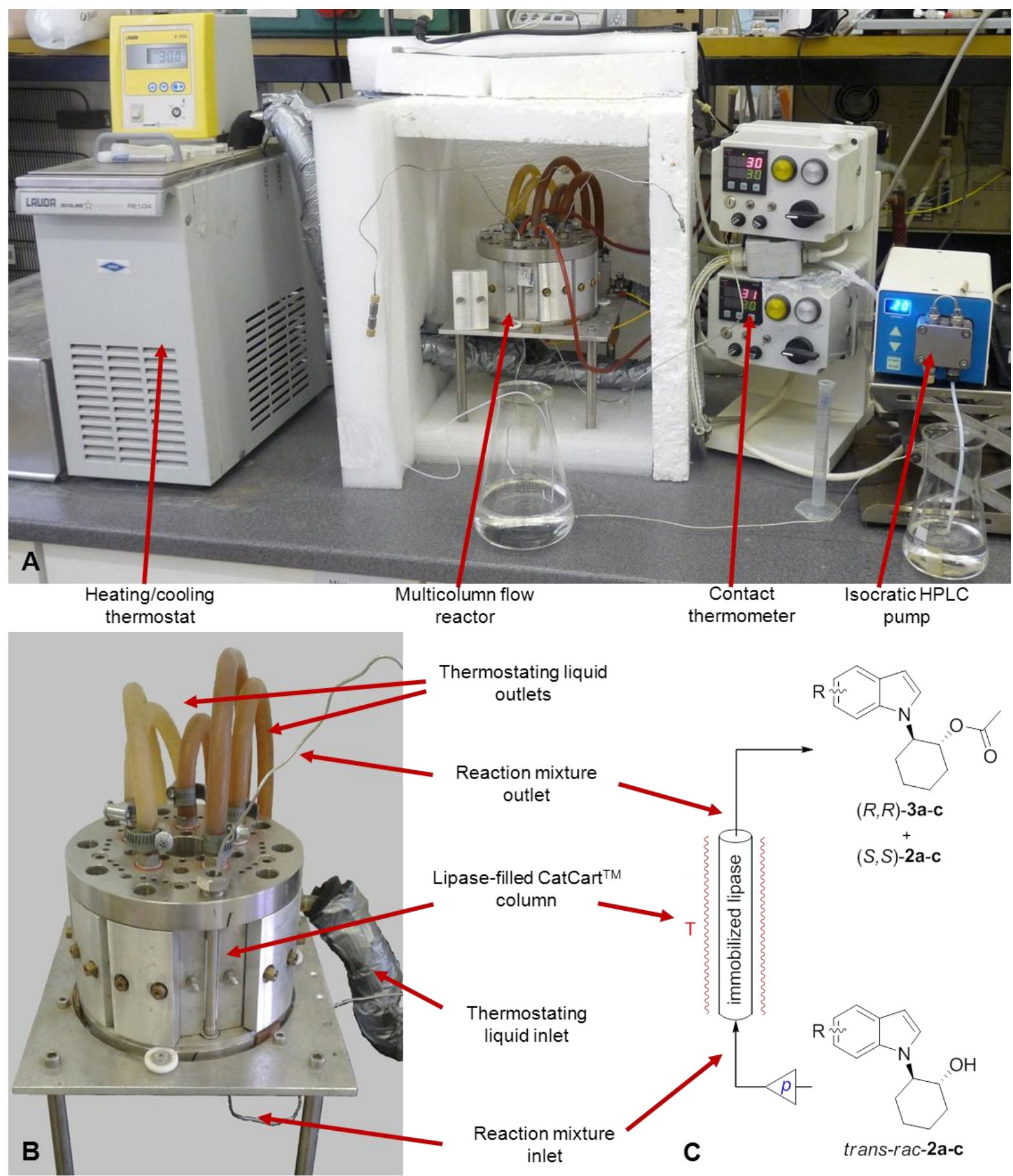

Figure 1. A multicolumn continuous-flow reactor system (A). The multicolumn reactor block (B) and the scheme of the KRs in the continuous-flow reactor $(\mathrm{C}: r a c-2 \mathrm{a}-\mathrm{c})$ are also shown.

Selection of biocatalysts to study the KRs of rac-2a-c in continuous-flow mode was based on the results of KRs of rac-2a-c in batch experiments. Thus, continuous-flow KRs were investigated using Amano AK, CaLA Dv250P, CaLB N435, Lipobond PS, Lipozyme MmL and Lipozyme TLIM for rac-2a, further CaLB N435, Lipobond PS, Lipozyme MmL and Lipozyme TLIM for $r a c-\mathbf{2 b}$ and $r a c-2 c$. A solution of $r a c-\mathbf{2 a}-\mathbf{c}$ and vinyl acetate in hexanetert-butyl methyl ether (2:1) was pumped through the lipase filled column thermostated to a 
certain temperature $\left(10^{\circ} \mathrm{C}\right.$ steps in the $0^{\circ} \mathrm{C}$ to $60^{\circ} \mathrm{C}$ or $0^{\circ} \mathrm{C}$ to $70^{\circ} \mathrm{C}$ range) at a flow rate of 0.2 $\mathrm{mL} / \mathrm{min}$. Samples were taken when reaching the stationary state (30 min after starting a new run) and analysed by GC (Section 4.2.).

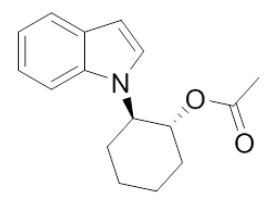

$(R, R)-3 a$

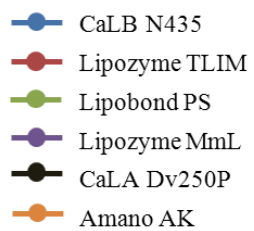

- Amano AK
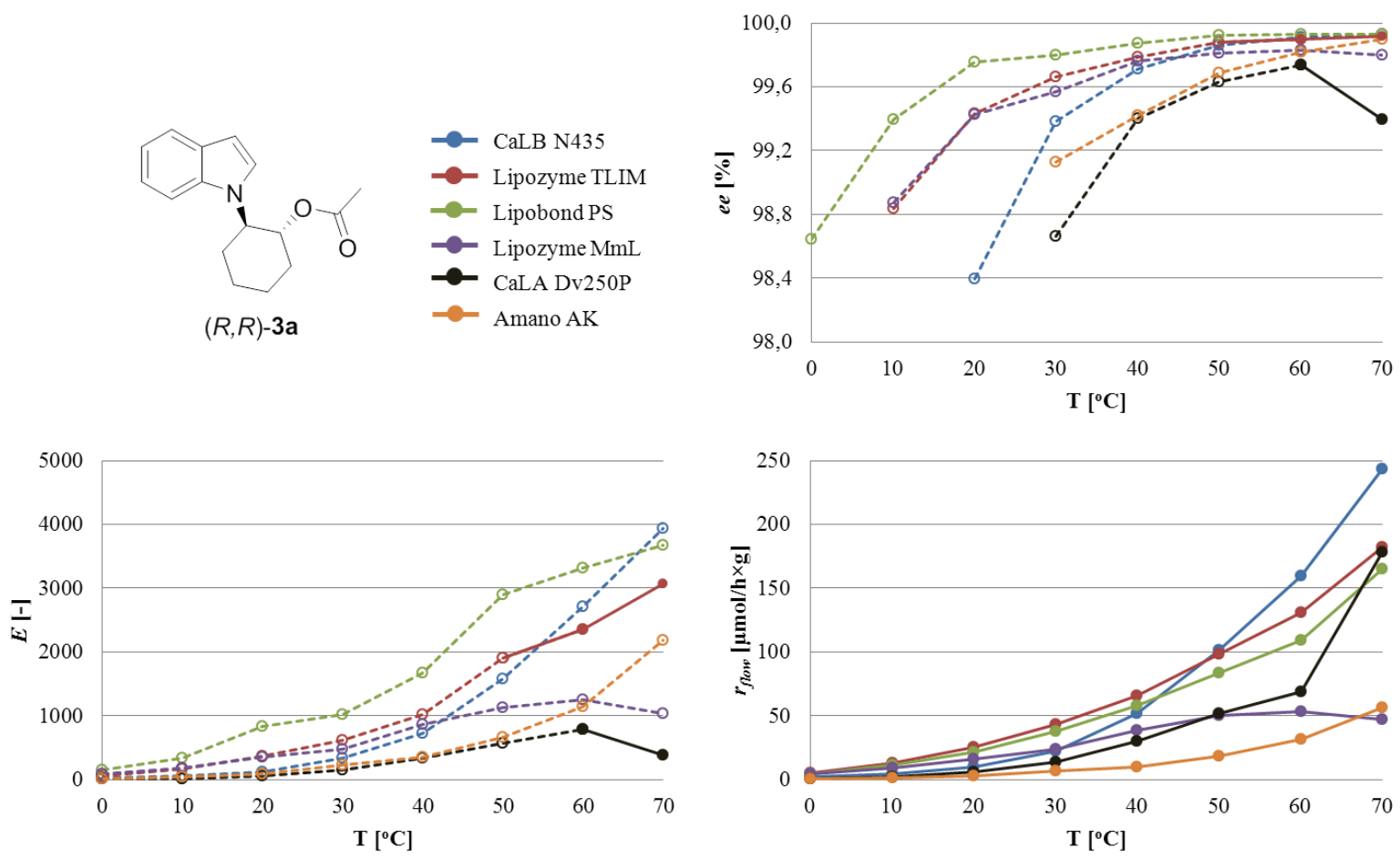

Figure 2. Temperature dependent biocatalytic properties $\left(E, e e\right.$ and $\left.r_{\text {flow }}\right)$ of various lipase biocatalysts in the kinetic resolution of $r a c-\mathbf{2 a}$ by acylation with vinyl acetate in a continuous-flow reactor. Unfilled markers and dashed lines are from GC measurements with the minor enantiomers under detection limits; see Section 4.2.

The results of KRs of rac-2a in continuous-flow mode are shown in Figure 2. In accordance with the KRs in batch mode, the different biocatalysts exhibited diverse productivity (specific reaction rate, $r_{\text {flow }}$ ) but less variable and high enantiomer selectivity $(E$ values from $>100$ to $\gg 200$, between 20 and $60^{\circ} \mathrm{C}$ ). All active biocatalysts behaved similarly and their productivity increased exponentially between 0 and $70^{\circ} \mathrm{C}$, except for Lipozyme $\mathrm{MmL}$ (where $r_{\text {flow }}$ stopped increasing at around $50^{\circ} \mathrm{C}$ ). This indicated the thermostability of all investigated lipases, except of Lipozyme $\mathrm{MmL}$ up to $70^{\circ} \mathrm{C}$ under the investigated continuousflow conditions. Lipozyme TLIM showed the highest productivity $\left(0-40^{\circ} \mathrm{C}\right)$ while Amano AK was the least active in KR of rac-2a in continuous-flow mode. Lipobond PS was the most selective biocatalyst in the ambient temperature regime between 20 and $50^{\circ} \mathrm{C}(E \gg 200$ and $e e_{(R, R)-3 \mathrm{a}}$ from 99.8 to $\left.>99.9 \%\right)$ and even at high temperature such as $70^{\circ} \mathrm{C}\left(E \gg 200\right.$ and $e e_{(R, R)-}$ 3a $>99.9 \%$ ). Although CaLB N435 did not show notable productivity in the lower temperature range (below $20^{\circ} \mathrm{C}$ ), its productivity increased drastically from $30^{\circ} \mathrm{C}$ and it was the most active catalyst above $50^{\circ} \mathrm{C}$. Importantly, it exhibited also excellent selectivity at $70^{\circ} \mathrm{C}(E » 200$ and $\left.e e_{(R, R)-3 \mathbf{a}}>99.9 \%\right)$. CaLA Dv250P behaved differently than the other biocatalysts. In a 
wide range of temperature $\left(0-60^{\circ} \mathrm{C}\right)$ its productivity $\left(r_{\text {flow }}\right)$ increased only moderately but $r_{\text {flow }}$ almost tripled when the temperature rose from $60^{\circ} \mathrm{C}$ to $70^{\circ} \mathrm{C}$. CaLA Dv250P was the only catalyst with significant drop in selectivity at high temperature: $e e_{(R, R)-3 \mathrm{a}}$ dropped from $99.7 \%$ at $60^{\circ} \mathrm{C}$ to $99.4 \%$ at $70^{\circ} \mathrm{C}$.

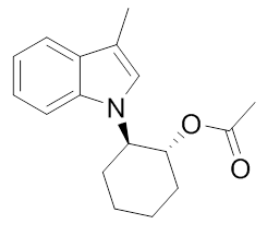

$(R, R)-3 \mathrm{~b}$

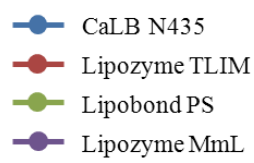

- Lipozyme MmL
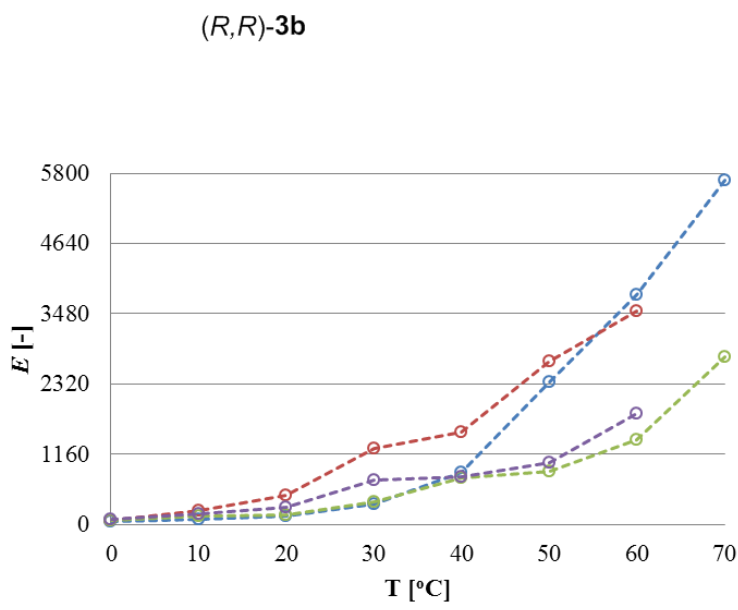
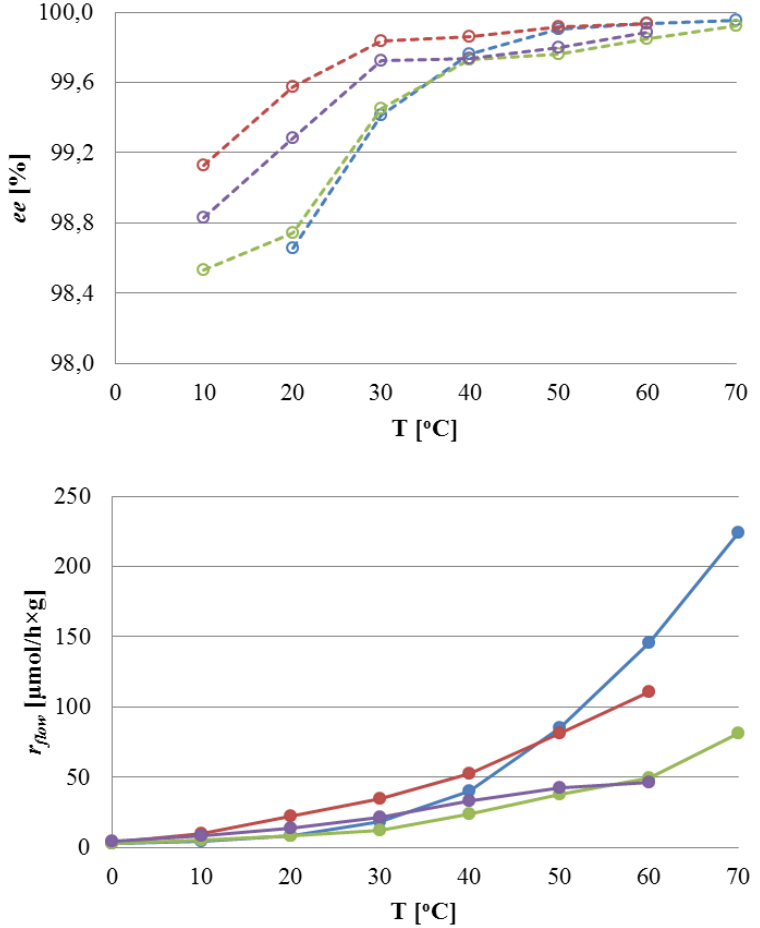

Figure 3. Temperature dependent biocatalytic properties $\left(E, e e\right.$ and $\left.r_{f l o w}\right)$ of various lipase biocatalysts in kinetic resolution of rac-2b by acylation with vinyl acetate in a continuous-flow reactor. Unfilled markers and dashed lines are from GC measurements with the minor enantiomers under detection limits; see Section 4.2.

Those four lipases (CaLB N435, Lipobond PS, Lipozyme TLIM and Lipozyme MmL) which showed the highest activities in batch mode KRs of the 3-methyl-substituted-indole substrate (rac-2b, Entries 12-15 in Table 1) were further studied at various temperatures in the continuous-flow mode KRs of rac-2b (Figure 3). Investigations of the two most active ones (CaLB N435 and Lipobond PS) between $0-70^{\circ} \mathrm{C}$ and the further two (Lipozyme TLIM and Lipozyme $\mathrm{MmL}$ ) between $0-60^{\circ} \mathrm{C}$ (Figure 3) showed quite similar temperaturedependent biocatalytic behaviour to those found in the KRs of rac-2a (Figure 2). At the low temperature range $\left(0-20^{\circ} \mathrm{C}\right) \mathrm{CaLB} N 435$ was almost inactive in the $\mathrm{KR}$ of rac-2b, while in the range of $20-70^{\circ} \mathrm{C}$ exponential ascend of $r_{\text {flow }}$ was observed. CaLB N435 and Lipozyme TLIM were the most selective lipases in the KR of $r a c$-2b above $50^{\circ} \mathrm{C}\left(E \gg 200\right.$ and $e e_{(R, R)-3 \mathbf{b}}$ \99.9\%). Lipobond PS exhibited lower but still exponentially increasing productivity from $0^{\circ} \mathrm{C}$ to $70^{\circ} \mathrm{C}$ with excellent selectivity at high temperature $\left(E » 200\right.$ and $e e_{(R, R)-3 \mathbf{b}}>99.9 \%$ at $70^{\circ} \mathrm{C}$ ). Thermostability of Lipozyme MmL proved to be poor in the continuous-flow KR of $r a c-\mathbf{2 b}$ as well, because $r_{\text {flow }}$ did not increase above $50^{\circ} \mathrm{C}$. 


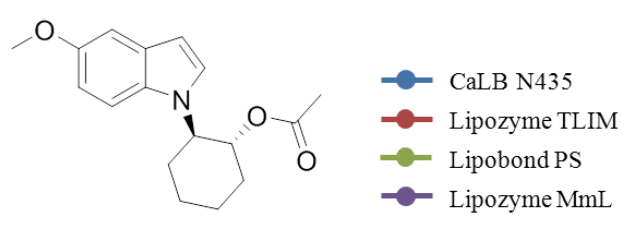

$(R, R)-3 \mathbf{c}$

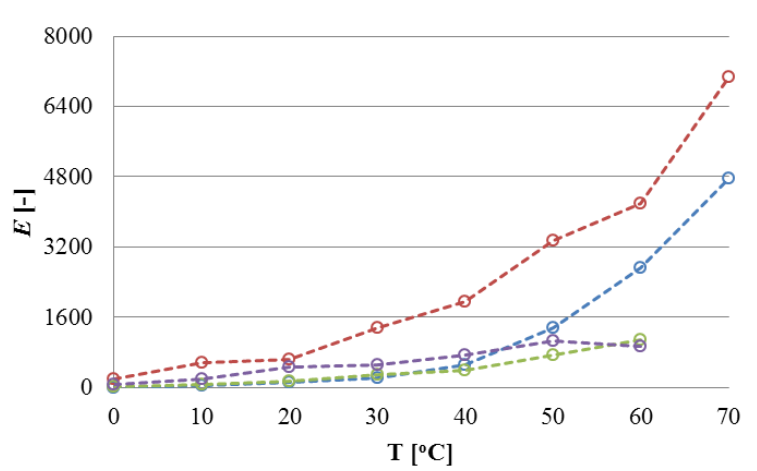

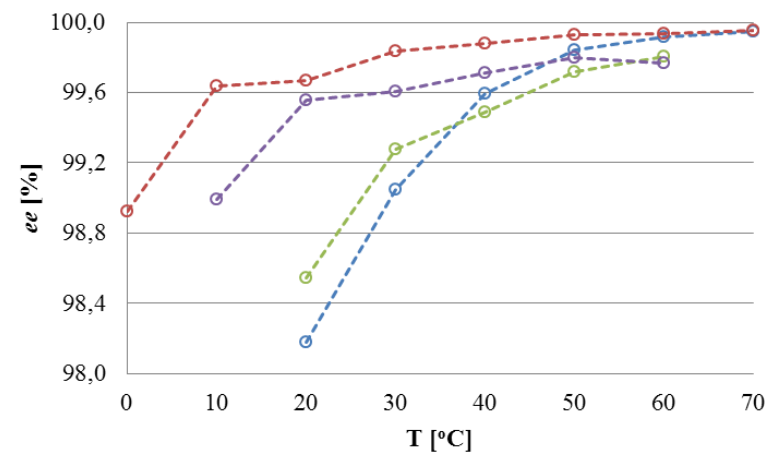

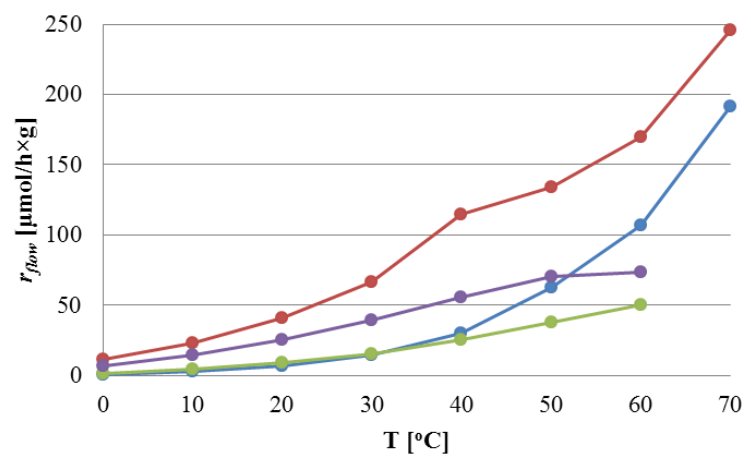

Figure 4. Temperature dependent biocatalytic properties $\left(E, e e\right.$ and $\left.r_{\text {flow }}\right)$ of various lipase biocatalysts in kinetic resolution of rac-2c by acylation with vinyl acetate in a continuous-flow reactor. Unfilled markers and dashed lines are from GC measurements with the minor enantiomers under detection limits; see Section 4.2.

Again, the four lipases (CaLB N435, Lipobond PS, Lipozyme TLIM and Lipozyme MmL) showing the highest activity in batch mode KRs of the 5-methoxy-substituted-indole substrate (rac-2c, Entries 20-23 in Table 1) were studied at various temperatures in the continuousflow mode KRs as well (Figure 4). In this case, the two most active biocatalysts (Lipozyme TLIM and CaLB N435) were studied between $0-70^{\circ} \mathrm{C}$ and the further two (Lipobond PS and Lipozyme $\mathrm{MmL}$ ) only between $0-60^{\circ} \mathrm{C}$ (Figure 3). In accordance with the results in batch mode KRs (Table 1, Panel C) the highest productivity in the whole temperature range (0$70^{\circ} \mathrm{C}$ ) was achieved with Lipozyme TLIM combined with excellent selectivity $[E \gg 200$ and monotonically increasing $e e_{(R, R)-3 \mathrm{c}}$ from $99.6 \%\left(10^{\circ} \mathrm{C}\right)$ to $\left.>99.9 \%\left(70^{\circ} \mathrm{C}\right)\right]$. Contrarily to the KRs of rac-2a or rac-2b, where CaLB N435 was the most active biocatalyst in the high temperature range of $50-70^{\circ} \mathrm{C}$, its productivity remained lower than that of Lipozyme TLIM in the KRs of rac-2b at any temperature covered. Although Lipozyme MmL showed good enantiomer selectivity in the ambient temperature range $\left(E\right.$ from $>200$ to $\gg 200$ and $e e_{(R, R)-3 \mathrm{c}}$ from $99.6 \%$ to $99.8 \%$ between $20-60^{\circ} \mathrm{C}$ ), its applicability is limited due to the partial deactivation of the enzyme above $50^{\circ} \mathrm{C}$. In contrast to the KRs of rac-2a, the lowest productivity was obtained with Lipobond PS although selectivity with good above $50^{\circ} \mathrm{C}$ ( $E$ $\gg 200$ and $\left.e e_{(R, R)-3 \mathrm{c}}>99.7 \%\right)$. 
In conclusion, generally higher productivity can be obtained at the high temperature range $\left(50-70^{\circ} \mathrm{C}\right)$ with all the investigated biocatalysts but Lipozyme MmL. Enantiomeric selectivity of the lipase-catalysed KRs of $r a c-\mathbf{2 a}-\mathbf{c}$ did not drop with increasing temperature due to the fact that trans-1-(2-hydroxycyclohexyl)-indoles $($ rac-2a-c) are rather bulky and conformationally rigid substrates.

\subsection{Preparation of enantiomerically enriched alcohols $(2 a-c)$ and acetates $(3 a-c)$ in}

\section{flow mode at preparative scale}

The crucial issue in the development of a preparative scale method is finding the optimal temperature at which productivity, selectivity and lifetime of the enzyme are balanced.. In general, productivity is increasing with increasing temperature, although at higher temperature lifetime of the biocatalyst may suffer decrease. Since the best overall performance in the continuous-flow KR of all the three substrates (rac-2a-c) could be achieved with CaLB N435 in the high temperature range $\left(r_{\text {flow }}>100 \mu \mathrm{mol} /(\mathrm{h} \times \mathrm{g}), E \gg 200\right.$ and $e e_{(R, R)-3 \mathrm{a}-\mathrm{c}}>99.9 \%$ at and above $\left.60^{\circ} \mathrm{C}\right)$, CaLB N435 was selected as biocatalyst to perform flow mode $\mathrm{KR}$ at preparative scale. The temperature was chosen to be $50-60^{\circ} \mathrm{C}$ where $\mathrm{CaLB}$ N435 has proved to be both productive and selective without the danger of losing its activity.

For all the three substrates (rac-2a-c) the same series of six CaLB N435-filled columns was used. Between the runs with different substrates the columns were washed briefly with hexane-tert-butyl methyl ether $(2: 1)$ with about ten times the dead volume of the bioreactor to remove substrate residues. After $24 \mathrm{~h}$ of continuous-flow operation at $50^{\circ} \mathrm{C}$, the bioreactor was switched to recirculation-flow mode at $60^{\circ} \mathrm{C}$ until the conversion reached nearly $50 \%$ or the $e e_{(R, R)-3 \mathbf{a}-\mathbf{c}}$ (monitored by GC) started to decrease. The obtained $(R, R)$-acetates $[(R, R)-\mathbf{3 a}-\mathbf{c}]$ and $(S, S)$-alcohols $[(S, S)$-2a-c] were separated by column chromatography and the acetates $[(R, R)-\mathbf{3 a}-\mathbf{c}]$ were deacylated by Zemplén deacylation to yield the $(R, R)$-alcohols $[(R, R)-\mathbf{2 a}-$ c] (Table 2). In most of the cases, high enantiomeric excesses values were observed; $(R, R)$ 3a-c,, $99.0 \% ;(R, R)-\mathbf{2 a}-\mathbf{c},>97-98 \%$ and $(S, S)-\mathbf{2 b}-\mathbf{c},>93-94 \%$. Only with $(S, S)-\mathbf{2 a}$ was $e e_{(R, R)-}$ 2a $<90.0 \%$.

Table 2. Alcohols prepared by kinetic resolution of $\mathrm{rac}-\mathbf{2 a}-\mathbf{c}$ with vinyl acetate in a CaLB N435-filled continuous-flow reactor at preparative scale followed by Zemplén deacylation of the formed $(R, R)-\mathbf{3 a}-\mathbf{c}$.

\begin{tabular}{lccr}
\hline Compound & Yield $(\%)$ & $e e(\%)^{a}$ & {$[\alpha]_{D}^{26^{\circ} \mathrm{Cb}}$} \\
\hline$(R, R)-\mathbf{2 a}$ & $36^{c}$ & 97.8 & +0.86 \\
$(S, S)-\mathbf{2 a}$ & 39 & 87.9 & -0.75 \\
$(R, R)-\mathbf{2 b}$ & $33^{c}$ & 98.1 & +0.17 \\
$(S, S)-\mathbf{2 b}$ & 34 & 94.8 & -0.07 \\
$(R, R)-\mathbf{2 c}$ & $35^{c}$ & 98.7 & +0.47 \\
$(S, S)-\mathbf{2 c}$ & 33 & 93.1 & -0.19
\end{tabular}


$\begin{array}{llll}(R, R)-3 \mathbf{a} & 45 & 99.1 & +12.7\end{array}$

$\begin{array}{llll}(R, R)-3 \mathbf{b} & 43 & 99.5 & +10.7\end{array}$

$\begin{array}{llll}(R, R)-3 \mathrm{c} & 42 & 99.2 & +11.8\end{array}$

${ }^{a}$ Enantiomeric excess was determined by chiral GC (see Section 4.2).

${ }^{b}$ Specific rotations, $\left(c 1.0, \mathrm{CH}_{2} \mathrm{Cl}_{2}\right)$.

${ }^{c}$ Combined yield of kinetic resolution and Zemplén deacylation.

During these runs, the CaLB N435-filled columns were used for more than three weeks in total. After all the continuous- and recirculation-flow runs with the three different substrates (rac-2a-c), testing of the spent CaLB N435-filled columns by KR of the unsubstituted 2-(1indolyl)cyclohexanol ( $\mathrm{rac}-\mathbf{2 a})$, between $30-60^{\circ} \mathrm{C}$, indicated no observable change in activity or selectivity compared to the first single column tests (Figure 2).

\section{Conclusion}

Batch and continuous-flow methods were investigated for the first time for the lipasecatalysed kinetic resolution of trans-1-(2-hydroxycyclohexyl)-indoles (rac-2a-c) by acetylation with vinyl acetate. The substrates $r a c-\mathbf{2 a}-\mathbf{c}$ could be obtained conveniently by ring opening of cyclohexene oxide with the corresponding indole $(\mathbf{1 a}-\mathbf{c})$. We studied the influence of temperature effect on productivity and selectivity in the $0-70^{\circ} \mathrm{C}$ range and found that a number of the thermostable biocatalysts produced higher productivity with excellent enantiomer selectivity in the continuous-flow KRs of rac-2a-c in the high temperature range $\left(50-70^{\circ} \mathrm{C}\right)$ than at low temperatures. Based on this observation, highly enantiomerically enriched alcohols $(\mathbf{2 a}-\mathbf{c})$ and acetates $(\mathbf{3 a}-\mathbf{c})$ were produced by flow mode methods at preparative scale by using a CaLB N435 filled reactor operating at $50-60^{\circ} \mathrm{C}$.

\section{Experimental}

\subsection{Materials}

All chemicals and starting materials were purchased from Sigma-Aldrich (Saint Louis, MO, USA) and Alfa Aesar Europe (Karlsruhe, Germany) and used without further purification.

Prior to use, solvents from Merck KGaA (Darmstadt, Germany) were dried and/or freshly distilled.

Amano A (lipase from Aspergillus niger), Amano AK (lipase from Pseudomonas fluorescens), Amano AYS (lipase from Candida rugosa), Amano F-AP15 (lipase from Rhizopus oryzae), Amano G (lipase from Penicillium camamberti), Amano M (lipase from Mucor javanicus), Amano PS (lipase from Burkholderia cepacia), CrL (lipase from Candida rugosa), Lipozyme ${ }^{\circledR} \mathrm{MmL}$ (Lipozyme MmL, lipase from Mucor miehei, immobilized on 
macroporous ion-exchange resin), Lipozyme $^{\circledR}$ TLIM (Lipozyme TLIM, lipase from Thermomyces lanuginosus, immobilized on ion-exchange resin), Novozym ${ }^{\circledR} 435$ (CaLB N435, lipase B from Candida antarctica, adsorbed on acrylic resin) and PPL (lipase from porcin pancreas) were purchased from Sigma Aldrich (Saint Louis, MO, USA). CaLA T2-150 (lipase A from Candida antarctica, covalently attached to dry acrylic beads of 150-300 $\mu \mathrm{m}$ particle size) and CaLB T2-150 (lipase B from Candida antarctica, covalently attached to dry acrylic beads of 150-300 $\mu \mathrm{m}$ particle size) were the products of ChiralVision BV (Leiden, The Netherlands). Lipobond PS (liase from Burkholderia cepacia, covalently immobilized on a highly hydrophobic support) was obtained from Iris Biotech GmbH (Marktredwitz, Germany). AK Dv250P (lipase from Pseudomonas fluorescens, adsorbed on phenylfunctionalized silica gel), CaLA Dv250P (lipase from Candida antarctica, adsorbed on phenyl-functionalized silica gel), CaLB Dv250P (lipase from Candida antarctica, adsorbed on phenyl-functionalized silica gel), CrL Dv250O (lipase from Candida rugosa, adsorbed on octyl-functionalized silica gel), MpL Dv250O (lipase from Malbranchea pulchella, adsorbed on octyl-functionalized silica gel), MpL Dv250P (lipase from Malbranchea pulchella, adsorbed on phenyl-functionalised silica gel), PaL Dv250P (lipase from Pseudozyma aphidis, adsorbed on phenyl-functionalised silica gel) and PS Dv250O (lipase from Burkholderia cepatia, adsorbed on octyl-functionalized silica gel) were the products of SynBiocat Ltd. (Budapest, Hungary).

\subsection{Methods}

TLC was carried out using Kieselgel $60 \mathrm{~F}_{254}$ (Merck) sheets. Spots were visualized under UV light $(254 \mathrm{~nm}$ and $365 \mathrm{~nm})$ or by treatment with $5 \%$ ethanolic phosphomolybdic acid solution and heating of the dried plates. Optical rotations were taken on a Perkin-Elmer 241 polarimeter that was calibrated by measuring the optical rotations of both enantiomers of menthol. The NMR spectra were recorded in $\mathrm{CDCl}_{3}$ on a Bruker DRX-300 spectrometer operating at $300 \mathrm{MHz}$ for ${ }^{1} \mathrm{H}$ and $75 \mathrm{MHz}$ for ${ }^{13} \mathrm{C}$, and signals are given in ppm on the $\delta$ scale. Infrared spectra were recorded on a Bruker ALPHA FT-IR spectrometer and wavenumbers of bands are listed in $\mathrm{cm}^{-1}$.

Reactions were analysed by GC on an Agilent 5890 equipment using Hydrodex $\beta$-TBDAc column (Machery-Nagel; $25 \mathrm{~m} \times 0.25 \mathrm{~mm} \times 0.25 \mu \mathrm{m}$, heptakis-(2,3-di-O-acetyl-6- $O$ - $t$-butyldimethylsilyl)- $\beta$-cyclodextrin) [FID $\left(250^{\circ} \mathrm{C}\right)$, injector $\left(250^{\circ} \mathrm{C}\right), \mathrm{H}_{2}(12 \mathrm{psi}$, split ratio: 1:50)]. GC data [(oven program); $\left.t_{\mathrm{r}}(\mathrm{min})\right]$ : for $\mathbf{2 a}$ and $\mathbf{3 a}\left[\left(100-190^{\circ} \mathrm{C}, 9^{\circ} \mathrm{C} / \mathrm{min}, 15 \mathrm{~min}\right.\right.$ at $\left.190^{\circ} \mathrm{C}\right)$, $(S, S)-3 \mathbf{a}: 18.9,(R, R)-3 \mathbf{a}: 19.4,(S, S)-\mathbf{2 a}: 21.1,(R, R)-\mathbf{2 a}: 21.6]$; for $\mathbf{2 b}$ and $\mathbf{3 b}\left[\left(100-190^{\circ} \mathrm{C}\right.\right.$, 
$9^{\circ} \mathrm{C} / \mathrm{min}, 20 \mathrm{~min}$ at $\left.190^{\circ} \mathrm{C}\right)$; $\left.(S, S)-3 \mathbf{b}: 20.9,(R, R)-3 \mathbf{b}: 21.4,(S, S)-2 \mathbf{a}: 24.9,(R, R)-2 \mathbf{a}: 25.5\right]$; for 2c and 3c [(45 min at $\left.\left.190^{\circ} \mathrm{C}\right) ;(S, S)-3 \mathbf{c}: 30.9,(R, R)-3 \mathbf{c}: 32.0,(S, S)-2 c: 37.2,(R, R)-2 \mathrm{c}: 38.2\right]$. In Figures $2-4$, data points are shown only for cases with $e e>98.0 \%$. The solid curves and filled markers indicate data which arose from a precise integration of chromatograms in which both enantiomers of the products 3a-c were clearly visible. When signals for the minor enantiomer $[(S, S)-3 \mathbf{a}-\mathbf{c}]$ were indistinguishable from noise, the dashed lines and unfilled markers indicate values which are possible minimum values of $e e$ and $E$.

Conversion $(c)$, enantiomeric excess $(e e)$ and enantiomeric ratio $(E)$ were determined by GC. Enantiomeric ratio $(E)$ was calculated from $c$ and enantiomeric excess of the product $\left(e e_{\mathrm{P}}\right)$ using the equation $E=\ln \left[1-c\left(1+e e_{\mathrm{P}}\right)\right] / \ln \left[1-c\left(1-e e_{\mathrm{P}}\right)\right]{ }^{68}$ For simplicity, $E$ values calculated in the range of 100-200 were given as $>100$, those in the range of 200-500 as $>200$ and above 500 as $\gg 200$. To characterize the productivity of the biocatalysts, specific reaction rates in batch reactions $\left(r_{\text {batch }}\right)$ were calculated using the equation $r_{\text {batch }}=n_{\mathrm{P}} /\left(t \times m_{\mathrm{B}}\right)\left(\right.$ where $n_{\mathrm{P}}$ [ $\mu \mathrm{mol}]$ is the amount of the product, $t[\mathrm{~h}]$ is the reaction time and $m_{\mathrm{B}}[\mathrm{g}]$ is the mass of the applied biocatalyst). ${ }^{65}$ Specific reaction rates in continuous-flow systems $\left(r_{\text {flow }}\right)$ were calculated using the equation $r_{\text {flow }}=[P] \times v / m_{\mathrm{B}}$ (where $[P][\mu \mathrm{mol} / \mathrm{mL}]$ is the molar concentration of the product, $v[\mathrm{~mL} / \mathrm{h}]$ is the flow rate and $m_{\mathrm{B}}[\mathrm{g}]$ is the mass of the applied biocatalyst). ${ }^{65}$ Because the rate of product formation is not a linear function of $c$, rigorous comparisons between the productivity of a continuous-flow reaction and its batch mode counterpart using their $r$ values can only be made at comparable degrees of conversions. ${ }^{65}$

Continuous-flow kinetic resolutions were performed in a laboratory flow reactor comprising an isocratic HPLC pump (Knauer K-120) attached to stainless steel columns (ThalesNano CatCart ${ }^{\mathrm{TM}}$ ) filled with the immobilized lipase biocatalysts in an in-house made thermostated aluminium metal block multicolumn holder with precise temperature control (Figure 1). Before use, the lipase-filled columns were washed with a 2:1 mixture of hexane and tert-butyl methyl ether $(0.5 \mathrm{~mL} / \mathrm{min}, 20 \mathrm{~min})$.

Enzymes were filled into stainless steel CatCart ${ }^{\mathrm{TM}}$ columns according to the process of ThalesNano Inc. For the continuous-flow enzymatic applications both ends of the columns were sealed with PTFE sealings and silver metal filter membranes (Sterlitech Silver Membrane Filter from Sigma-Aldrich, Z623237, pore size $0.45 \mu \mathrm{m}$; pure metallic silver, 99.97\% with no extractable or detectable contaminants). 


\subsection{Synthesis of racemic secondary alcohols (rac-2a-c)}

Secondary alcohols were obtained by a slightly modified method of Gharpure, J. S. and Sathiyanarayanan, A. M. ${ }^{67}$ A solution of the indole (1a: $0.854 \mathrm{~mol}, \mathbf{1 b}: 0.381 \mathrm{~mol}, \mathbf{1 c}: 0.340$ mol) in dry DMF (40 mL) was added dropwise to a stirred suspension of $\mathrm{NaH}$ (1 equiv.) in dry DMF $(60 \mathrm{~mL})$ at $0^{\circ} \mathrm{C}$ over $15 \mathrm{~min}$. After stirring at $0^{\circ} \mathrm{C}$ for $20 \mathrm{~min}$, cyclohexene oxide (1 equiv.) was added and the resulting slurry was allowed to warm to room temperature and stirred overnight. Then the reaction mixture was stirred under reflux. When the reaction was completed (monitored by TLC, eluent: $\mathrm{CH}_{2} \mathrm{Cl}_{2}$ ), it was cooled, quenched by water $(50 \mathrm{~mL})$ and extracted with diethyl ether $(3 \times 50 \mathrm{~mL})$. The combined organic phases were washed with brine $(2 \times 50 \mathrm{~mL})$, dried over $\mathrm{Na}_{2} \mathrm{SO}_{4}$ and the solvent was removed under vacuum. The residue was further purified by column chromatography on silica gel eluted with $\mathrm{CH}_{2} \mathrm{Cl}_{2}$.

rac-2a: $17.82 \mathrm{~g} \mathrm{(97 \% ),} \mathrm{pale} \mathrm{yellow} \mathrm{crystals,} \mathrm{mp}: 85.2-86.0^{\circ} \mathrm{C}, \mathrm{IR}\left(\mathrm{KBr}, \mathrm{cm}^{-1}\right): \vee 3238$, 3098, 2929, 2848, 1717, 1507, 1461, 1311, 1215, 1090, 739; ${ }^{1} \mathrm{H}$ NMR: 1.38-1.57 (2H, m, $\left.\mathrm{CH}_{2}\right), 1.76-1.93\left(4 \mathrm{H}, \mathrm{m}, \mathrm{CH}_{2}\right), 2.03-2.10\left(1 \mathrm{H}, \mathrm{m}, \mathrm{CH}_{2}\right), 2.17-2.24\left(1 \mathrm{H}, \mathrm{m}, \mathrm{CH}_{2}\right), 3.88(1 \mathrm{H}$, td, $J=9.80$ and $4.14 \mathrm{~Hz}, \mathrm{O}-\mathrm{CH}), 4.11(1 \mathrm{H}, \mathrm{td}, J=9.23$ and $3.96 \mathrm{~Hz}, \mathrm{~N}-\mathrm{CH}), 5.32(1 \mathrm{H}, \mathrm{s}, \mathrm{OH})$, $6.60(1 \mathrm{H}, \mathrm{d}, J=2.83 \mathrm{~Hz}, \mathrm{CH}), 7.11-7.28(3 \mathrm{H}, \mathrm{m}, \mathrm{CH}), 7.50(1 \mathrm{H}, \mathrm{d}, J=8.29 \mathrm{~Hz}, \mathrm{CH}), 7.66(1 \mathrm{H}$, d, J=7.24 Hz, CH); ${ }^{13} \mathrm{C}$ NMR: $24.55\left(\mathrm{CH}_{2}\right), 25.66\left(\mathrm{CH}_{2}\right), 32.02\left(\mathrm{CH}_{2}\right), 33.82\left(\mathrm{CH}_{2}\right), 62.19$ $(\mathrm{CH}), 73.89(\mathrm{CH}), 102.63(\mathrm{CH}), 110.07(\mathrm{CH}), 119.83(\mathrm{CH}), 121.19(\mathrm{CH}), 121.83(\mathrm{CH})$, $124.18(\mathrm{CH}), 128.67(\mathrm{C}), 136.98(\mathrm{C})$.

rac-2b: $8.08 \mathrm{~g}(92 \%)$, pale yellow crystals, mp: $91.1-92.9^{\circ} \mathrm{C}, \mathrm{IR}\left(\mathrm{KBr}, \mathrm{cm}^{-1}\right): \vee 3293$, 2929, 2851, 1755, 1612, 1553, 1464, 1357, 1224, 1204, 1086, 1015, 943, 735; ${ }^{1} \mathrm{H}$ NMR: 1.39-1.55 (2H, m, $\left.\mathrm{CH}_{2}\right), 1.65-1.92\left(4 \mathrm{H}, \mathrm{m}, \mathrm{CH}_{2}\right), 2.00-2.08\left(1 \mathrm{H}, \mathrm{m}, \mathrm{CH}_{2}\right), 2.16-2.25(1 \mathrm{H}, \mathrm{m}$, $\left.\mathrm{CH}_{2}\right) .2 .34\left(3 \mathrm{H}, \mathrm{s}, \mathrm{CH}_{3}\right), 3.80-3.92(1 \mathrm{H}, \mathrm{m}, \mathrm{O}-\mathrm{CH}), 3.99-4.10(1 \mathrm{H}, \mathrm{m}, \mathrm{N}-\mathrm{CH}), 5.30(1 \mathrm{H}, \mathrm{s}$, $\mathrm{OH}), 6.99(1 \mathrm{H}, \mathrm{s}, \mathrm{CH}), 7.08-7.16(1 \mathrm{H}, \mathrm{m}, \mathrm{CH}), 7.17-7.25(1 \mathrm{H}, \mathrm{m}, \mathrm{CH}), 7.43(1 \mathrm{H}, \mathrm{d}, J=8.23$ $\mathrm{Hz}, \mathrm{CH}), 7.58(1 \mathrm{H}, \mathrm{d}, J=7.91 \mathrm{~Hz}, \mathrm{CH}) ;{ }^{13} \mathrm{C} \mathrm{NMR}: 9.94\left(\mathrm{CH}_{3}\right), 24.60\left(\mathrm{CH}_{2}\right), 25.73\left(\mathrm{CH}_{2}\right)$, $32.06\left(\mathrm{CH}_{2}\right), 33.76\left(\mathrm{CH}_{2}\right), 61.97(\mathrm{CH}), 73.93(\mathrm{CH}), 109.83(\mathrm{C}), 111.92(\mathrm{CH}), 119.17(\mathrm{CH})$, $119.28(\mathrm{CH}), 121.72(\mathrm{CH}), 121.85(\mathrm{CH}), 128.91(\mathrm{C}), 137.34(\mathrm{C})$.

rac-2c: $8.18 \mathrm{~g}(98 \%)$, yellow oil, IR (film, $\mathrm{cm}^{-1}$ ): v 3270, 2933, 2856, 1620, 1479, 1448, 1233, 1151, 1067, 1030, 948, 792, 712; ${ }^{1} \mathrm{H}$ NMR: 1.37-1.52 (2H, m, $\left.\mathrm{CH}_{2}\right), 1.73-1.91$ (4H, m, $\left.\mathrm{CH}_{2}\right), 2.05\left(1 \mathrm{H}, \mathrm{m}, \mathrm{CH}_{2}\right), 2.19\left(1 \mathrm{H}, \mathrm{m}, \mathrm{CH}_{2}\right), 3.82-3.89\left(4 \mathrm{H}, \mathrm{m}, \mathrm{O}-\mathrm{CH}_{3}\right.$ and $\left.\mathrm{O}-\mathrm{CH}\right), 3.97-$ $4.07(1 \mathrm{H}, \mathrm{m}, \mathrm{N}-\mathrm{CH}), 5.31(1 \mathrm{H}, \mathrm{s}, \mathrm{OH}), 6.46-6.54(1 \mathrm{H}, \mathrm{m}, \mathrm{CH}), 6.86-6.93(1 \mathrm{H}, \mathrm{m}, \mathrm{CH}), 7.08-$ $7.13(1 \mathrm{H}, \mathrm{m}, \mathrm{CH}), 7.15-7.20(1 \mathrm{H}, \mathrm{m}, \mathrm{CH}), 7.36(1 \mathrm{H}, \mathrm{d}, J=8.85 \mathrm{~Hz}, \mathrm{CH}) ;{ }^{13} \mathrm{C} \mathrm{NMR}: 24.55$ $\left(\mathrm{CH}_{2}\right), 25.67\left(\mathrm{CH}_{2}\right), 32.02\left(\mathrm{CH}_{2}\right), 33.81\left(\mathrm{CH}_{2}\right), 56.08\left(\mathrm{CH}_{3}\right), 62.44(\mathrm{CH}), 73.98(\mathrm{CH}), 102.18$ 
$(\mathrm{CH}), 102.72(\mathrm{CH}), 110.81(\mathrm{CH}), 112.24(\mathrm{CH}), 124.77(\mathrm{CH}), 128.97(\mathrm{C}), 132.26(\mathrm{C}), 154.33$ (C).

\subsection{Synthesis of racemic acetates (rac-3a-c)}

To a mixture of the corresponding alcohol (2a: $1.39 \mathrm{mmol}, \mathbf{2 b}: 1.31 \mathrm{mmol}, \mathbf{2 c}: 1.22 \mathrm{mmol})$ in acetic anhydride $(2 \mathrm{~mL})$, catalytic amount (1 drop) of cc. $\mathrm{H}_{2} \mathrm{SO}_{4}$ was added at room temperature and the resulting slurry was stirred for $1 \mathrm{~min}$ (the reaction completed by TLC). After adding hexane $(5 \mathrm{~mL})$ to the mixture, it was washed with $10 \% \mathrm{Na}_{2} \mathrm{CO}_{3}(3 \times 5 \mathrm{~mL})$ and brine $(5 \mathrm{~mL})$, the organic phase was dried over $\mathrm{Na}_{2} \mathrm{SO}_{4}$ and the solvent was removed under vacuum. No further purification was necessary.

rac-3a: $83 \mathrm{mg}(23 \%)$, white crystals, $\mathrm{mp}: 63.3-65.2^{\circ} \mathrm{C}, \mathrm{IR}\left(\mathrm{KBr}, \mathrm{cm}^{-1}\right): v 3045,2939$, 2860, 1748, 1607, 1510, 1475, 1460, 1373, 1314, 1229, 1034, 745; ${ }^{1} \mathrm{H}$ NMR: 1.41-1.67 (3H, $\left.\mathrm{m}, \mathrm{CH}_{2}\right), 1.81-2.03\left(3 \mathrm{H}, \mathrm{m}, \mathrm{CH}_{2}\right), 2.11-2.27\left(2 \mathrm{H}, \mathrm{m}, \mathrm{CH}_{2}\right), 4.26-4.36(1 \mathrm{H}, \mathrm{m}, \mathrm{N}-\mathrm{CH}), 5.07-$ $5.21(1 \mathrm{H}, \mathrm{m}, \mathrm{O}-\mathrm{CH}), 6.54-6.56(1 \mathrm{H}, \mathrm{m}, \mathrm{CH}), 7.05-7.15(1 \mathrm{H}, \mathrm{m}, \mathrm{CH}), 7.17-7.30(2 \mathrm{H}, \mathrm{m}, \mathrm{CH})$, $7.44(1 \mathrm{H}, \mathrm{d}, J=8.28 \mathrm{~Hz}, \mathrm{CH}), 7.62(1 \mathrm{H}, \mathrm{d}, J=7.89 \mathrm{~Hz}, \mathrm{CH}) ;{ }^{13} \mathrm{C} \mathrm{NMR}: 20.47\left(\mathrm{CH}_{3}\right), 24.41$ $\left(\mathrm{CH}_{2}\right), 25.40\left(\mathrm{CH}_{2}\right), 31.97\left(\mathrm{CH}_{2}\right), 32.15\left(\mathrm{CH}_{2}\right), 58.23(\mathrm{CH}), 75.04(\mathrm{CH}), 102.31(\mathrm{CH}), 109.83$ $(\mathrm{CH}), 119.47(\mathrm{CH}), 121.08(\mathrm{CH}), 121.37(\mathrm{CH}), 124.14(\mathrm{CH}), 128.50(\mathrm{C}), 136.94(\mathrm{C}), 170.08$ (CO).

rac-3b: $101 \mathrm{mg}(28 \%)$, brown crystals, $\mathrm{mp}: 78.4-80.1^{\circ} \mathrm{C}, \mathrm{IR}\left(\mathrm{KBr}, \mathrm{cm}^{-1}\right): v 3061,2939$, 2861, 1739, 1613, 1463, 1452, 1359, 1297, 1235, 1125, 1031, 739; ${ }^{1} \mathrm{H}$ NMR: 1.43-1.60 (3H, m, $\left.\mathrm{CH}_{2}, \mathrm{CH}_{3}\right), 1.78-1.95\left(3 \mathrm{H}, \mathrm{m}, \mathrm{CH}_{2}\right), 2.07-2.22\left(2 \mathrm{H}, \mathrm{m}, \mathrm{CH}_{2}\right), 2.30\left(3 \mathrm{H}, \mathrm{s}, \mathrm{CH}_{3}\right), 4.18-$ $4.28(1 \mathrm{H}, \mathrm{m}, \mathrm{N}-\mathrm{CH}), 5.02-5.11(1 \mathrm{H}, \mathrm{m}, \mathrm{O}-\mathrm{CH}), 6.94(1 \mathrm{H}, \mathrm{s}, \mathrm{CH}), 7.07(1 \mathrm{H}, \mathrm{t}, J=7.74 \mathrm{~Hz}$, $\mathrm{CH}), 7.18(1 \mathrm{H}, \mathrm{t}, J=7.16 \mathrm{~Hz}, \mathrm{CH}), 7.36(1 \mathrm{H}, \mathrm{d}, J=8.29 \mathrm{~Hz}, \mathrm{CH}), 7.52(1 \mathrm{H}, \mathrm{d}, J=7.91 \mathrm{~Hz}, \mathrm{CH})$; ${ }^{13} \mathrm{C}$ NMR: $9.95\left(\mathrm{CH}_{3}\right), 20.88\left(\mathrm{CH}_{3}\right), 24.44\left(\mathrm{CH}_{2}\right), 25.43\left(\mathrm{CH}_{2}\right), 31.98\left(\mathrm{CH}_{2}\right), 32.25\left(\mathrm{CH}_{2}\right)$, $57.96(\mathrm{CH}), 75.12(\mathrm{CH}), 109.65(\mathrm{CH}), 111.35(\mathrm{C}), 118.74(\mathrm{CH}), 119.06(\mathrm{CH}), 121.30(\mathrm{CH})$, $121.64(\mathrm{CH}), 128.74(\mathrm{C}), 137.30(\mathrm{C}), 170.22(\mathrm{CO})$.

rac-3c: $59 \mathrm{mg}(17 \%)$, white crystals, $\mathrm{mp}: 70.3-72.8^{\circ} \mathrm{C}, \mathrm{IR}\left(\mathrm{KBr}, \mathrm{cm}^{-1}\right): v 2997,2938$, 2855, 1732, 1618, 1484, 1453, 1376, 1254, 1233, 1157, 1125, 1033, 796, 717; ${ }^{1} \mathrm{H}$ NMR: 1.42-1.63 (3H, m, $\left.\mathrm{CH}_{2}\right), 1.82-1.99\left(3 \mathrm{H}, \mathrm{m}, \mathrm{CH}_{2}\right), 2.09-2.25\left(2 \mathrm{H}, \mathrm{m}, \mathrm{CH}_{2}\right), 3.85\left(3 \mathrm{H}, \mathrm{s}, \mathrm{CH}_{3}\right)$, 4.14-4.29 (1H, m, N-CH), 5.01-5.16 (1H, m, O-CH), $6.46(1 \mathrm{H}, \mathrm{s}, \mathrm{CH}), 6.87(1 \mathrm{H}, \mathrm{d}, J=9.0$ $\mathrm{Hz}, \mathrm{CH}), 7.07(1 \mathrm{H}, \mathrm{s}, \mathrm{CH}), 7.16(1 \mathrm{H}, \mathrm{s}, \mathrm{CH}), 7.31(1 \mathrm{H}, \mathrm{d}, J=9.0 \mathrm{~Hz}, \mathrm{CH}) ;{ }^{13} \mathrm{C} \mathrm{NMR}: 20.65$ $\left(\mathrm{CH}_{3}\right), 24.24\left(\mathrm{CH}_{3}\right), 25.23\left(\mathrm{CH}_{2}\right), 31.77\left(\mathrm{CH}_{2}\right), 31.96\left(\mathrm{CH}_{2}\right), 55.85\left(\mathrm{CH}_{2}\right), 58.29(\mathrm{CH}), 74.99$ $(\mathrm{CH}), 101.69(\mathrm{CH}), 102.33(\mathrm{C}), 110.42(\mathrm{CH}), 111.65(\mathrm{CH}), 124.51(\mathrm{CH}), 128.54(\mathrm{CH})$, $132.12(\mathrm{C}), 153.86(\mathrm{C}), 169.91(\mathrm{CO})$. 


\subsection{Enantiomer selective acetylation of racemic alcohols (rac-2a-c) in batch mode}

To a solution of the alcohol (25 mg, rac-2a-c) in hexane-tert-butyl methyl ether-vinyl acetate 6:3:1 (2 mL) in an amber screw cap vial, the enzyme $(25 \mathrm{mg})$ was added and the mixture was shaken $(1000 \mathrm{rpm})$ in the closed vial at $30^{\circ} \mathrm{C}$ for $72 \mathrm{~h}$. Samples $(50 \mu \mathrm{L}$, diluted with $\mathrm{CH}_{2} \mathrm{Cl}_{2}$ to $300 \mu \mathrm{L}$ ) were taken directly from the reaction mixture after $1,4,8,24,48$ and $72 \mathrm{~h}$ and analysed by GC as described in Section 4.2.

\subsection{Enantiomer selective acetylation of racemic alcohols $(r a c-2 a-c)$ in continuous-}

\section{flow bioreactors}

Separate CatCart ${ }^{\mathrm{TM}}$ columns were packed for each substrate $($ rac-2a-c) in this study [filling weights: for KRs of rac-2a (CaLA Dv250P: 202 mg, CaLB N435: 256 mg, Lipozyme TLIM: 290 mg, Amano AK: $411 \mathrm{mg}$, Lipobond PS: $307 \mathrm{mg}$ and Lipozyme MmL: $250 \mathrm{mg}$ ); for KRs of rac-2b (CaLB N435: 237 mg, Lipozyme TLIM: 286 mg, Lipobond PS: 276 mg and Lipozyme MmL: $233 \mathrm{mg}$ ); for KRs of rac-2c (CaLB N435: 224 mg, Lipozyme TLIM: $301 \mathrm{mg}$; Lipobond PS: $280 \mathrm{mg}$ and Lipozyme MmL: $245 \mathrm{mg}$ )].

The alcohol $(5 \mathrm{mg} / \mathrm{mL}, \mathrm{rac}-\mathbf{2 a}-\mathbf{c})$ dissolved in a 6:3:1 mixture of hexane-tert-butyl methyl ether-vinyl acetate was pumped through the enzyme-packed column thermostated at various temperatures $\left(0-70^{\circ} \mathrm{C}\right)$ at a flow rate of $0.2 \mathrm{~mL} / \mathrm{min}$. Experiments were run in $10^{\circ} \mathrm{C}$ steps at temperatures of $0-70^{\circ} \mathrm{C}$. Samples were collected after stationary operation has been established (sample size $100 \mu \mathrm{L}$, diluted with $\mathrm{CH}_{2} \mathrm{Cl}_{2}$ to $250 \mu \mathrm{L}$; taken 30 min after setting a new temperature) and analysed by GC as described in Section 4.2. Results for KRs of rac-2ac are shown in Figures 3-5, respectively.

4.7. Kinetic resolution of racemic alcohols $(\mathrm{rac}-2 \mathrm{a}-\mathrm{c})$ in continuous-flow bioreactors at preparative scale

A series of six serially-connected CaLB N435-filled CatCart ${ }^{\mathrm{TM}}$ columns (total filling weight: $1373 \mathrm{mg}$ ) was used for the preparative scale kinetic resolutions of the substrates (rac$\mathbf{2 a - c ) . ~ B e f o r e ~ a n d ~ a f t e r ~ e a c h ~ r u n , ~ t h e ~ s e t ~ o f ~ c o l u m n s ~ w a s ~ f l u s h e d ~ w i t h ~ a ~ 2 : 1 ~ m i x t u r e ~ o f ~}$ hexane-tert-butyl methyl ether $(0.5 \mathrm{~mL} / \mathrm{min}, 1 \mathrm{~h})$ and the washed columns were stored at $4{ }^{\circ} \mathrm{C}$.

The solution of the alcohol $(5 \mathrm{mg} / \mathrm{mL}$ of $r a c-2 a-c)$ in a $6: 3: 1$ mixture of hexane-tert-butyl methyl ether-vinyl acetate was pumped through the enzyme filled column series thermostated to $50^{\circ} \mathrm{C}$ at a flow rate of $0.15 \mathrm{~mL} / \mathrm{min}$. After collecting $\sim 210 \mathrm{~mL}(24 \mathrm{~h})$ of the reaction mixture the system was switched to recirculation at $60^{\circ} \mathrm{C}$ until the conversion reached $\sim 45-$ $47 \%$. To check the progress of the reaction, samples were collected (sample size $100 \mu \mathrm{L}$, diluted with $\mathrm{CH}_{2} \mathrm{Cl}_{2}$ to $250 \mu \mathrm{L}$ ) and analysed by $\mathrm{GC}$ as described in Section 4.2. 
After finishing the reaction (140-170 h) the solvent was removed under vacuum and the alcohol $[(S, S)-\mathbf{2 a}-\mathbf{c}]$ and acetate $[(R, R)-\mathbf{3 a}-\mathbf{c}]$ were separated by column chromatography on silica gel eluted with $\mathrm{CH}_{2} \mathrm{Cl}_{2}$.

$(S, S)-2 a: 0.421 \mathrm{~g}(39 \%)$, white crystals, mp: $79.5-81.3^{\circ} \mathrm{C},[\alpha]_{D}^{26^{\circ} \mathrm{C}}=-0.75\left(\mathrm{CH}_{2} \mathrm{Cl}_{2}\right)$, $e e=87.9 \%$ by GC, IR $\left(\mathrm{KBr}, \mathrm{cm}^{-1}\right): v 3427,3050,2928,2856,1610,1512,1463,1411,1312$, $1251,1059,947,765,738$.

(S,S)-2b: $0.367 \mathrm{~g}(34 \%)$, white crystals, mp: $74.8-76.1^{\circ} \mathrm{C},[\alpha]_{D}^{26^{\circ} \mathrm{C}}=-0.07\left(\mathrm{CH}_{2} \mathrm{Cl}_{2}\right)$, $e e=94.8 \%$ by GC, IR $\left(\mathrm{KBr}, \mathrm{cm}^{-1}\right): v 3251,3048,2930,2849,1753,1613,1555,1465,1385$, $1357,1225,1206,1128,1085,1015,942,805,736$.

$(S, S)-2 c: 0.351 \mathrm{~g}(33 \%)$, yellow oil, $[\alpha]_{D}^{26^{\circ} \mathrm{C}}=-0.19\left(\mathrm{CH}_{2} \mathrm{Cl}_{2}\right), e e=93.1 \%$ by GC, IR (film, $\left.\mathrm{cm}^{-1}\right): v$ 3412, 2933, 2857, 1720, 1619, 1547, 1480, 1448, 1347, 1234, 1210, 1152, 1067, $1032,949,793,714$.

$(R, R)$-3a: $0.580 \mathrm{~g}(45 \%)$, pale yellow crystals, mp: 76.1-77. ${ }^{\circ} \mathrm{C},[\alpha]_{D}^{26^{\circ} \mathrm{C}}=+12.7\left(\mathrm{CH}_{2} \mathrm{Cl}_{2}\right)$, $e e=99.0 \%$ by GC, IR $\left(\mathrm{KBr}, \mathrm{cm}^{-1}\right): v 3467,3055,2935,2859,1923,1742,1610,1556,1510$, $1461,1409,1370,1314,1230,1029,868,736,713$.

$(R, R)-3 b: 0.549 \mathrm{~g}(43 \%)$, white oil, $[\alpha]_{D}^{26^{\circ} \mathrm{C}}=+10.7\left(\mathrm{CH}_{2} \mathrm{Cl}_{2}\right), e e=99.5 \%$ by GC, IR (film, $\left.\mathrm{cm}^{-1}\right): v 3049,2937,2861,1734,1612,1461,1360,1297,1232,1195,1033,909,736$.

$(R, R)-3 \mathrm{c}: 0.531 \mathrm{~g}(42 \%)$, yellow crystals, mp: $65.1-66.1^{\circ} \mathrm{C},[\alpha]_{D}^{26^{\circ} \mathrm{C}}=+11.8\left(\mathrm{CH}_{2} \mathrm{Cl}_{2}\right)$, $e e=99.2 \%$ by GC, IR $\left(\mathrm{KBr}, \mathrm{cm}^{-1}\right): v 2930,2860,1731,1481,1450,1370,1231,1155,1028$, $851,795,714$.

\subsection{Zemplén deacetylation of acetates $[(R, R)-3 a-c]$}

To a solution of $(R, R)-3 \mathbf{a}-\mathbf{c}(0.50 \mathrm{~g})$ dissolved in dry methanol $(10 \mathrm{~mL}) 0.1$ equiv. of $\mathrm{CH}_{3} \mathrm{ONa}$ was added at $0^{\circ} \mathrm{C}$. The resulting solution was stirred at $0^{\circ} \mathrm{C}$ for $1.5 \mathrm{~h}$ then at room temperature until the completion of the reaction (14-18 h, monitored by TLC using $\mathrm{CH}_{2} \mathrm{Cl}_{2}$ as eluent). After removing the solvent under vacuum the residue was filtered through a thin layer of silica gel by eluting with a 20:1 mixture of $\mathrm{CH}_{2} \mathrm{Cl}_{2}$ and $\mathrm{CH}_{3} \mathrm{OH}$.

$(R, R)-\mathbf{2 a}: 0.339 \mathrm{~g}(81 \%)$, pale yellow crystals, mp: $85.9-86.7^{\circ} \mathrm{C},[\alpha]_{D}^{26^{\circ} \mathrm{C}}=+0.86\left(\mathrm{CH}_{2} \mathrm{Cl}_{2}\right)$, $e e=97.8 \%$ by GC, IR (film, $\left.\mathrm{cm}^{-1}\right): v$ 3387, 2933, 2856, 1508, 1477, 1459, 1410, 1309, 1209, $1065,948,869,735$.

$(R, R)-2 b: 0.321 \mathrm{~g}(76 \%)$, pale yellow oil, $[\alpha]_{D}^{26^{\circ} \mathrm{C}}=+0.17\left(\mathrm{CH}_{2} \mathrm{Cl}_{2}\right), e e=98.1 \%$ by GC, IR (film, $\mathrm{cm}^{-1}$ ): v 3406, 2932, 2857, 1612, 1460, 1357, 1218, 1191, 1066, 1030, 944, 733.

$(R, R)$-2c: $0.359 \mathrm{~g}(84 \%)$, yellow oil, $[\alpha]_{D}^{26^{\circ} \mathrm{C}}=+0.47\left(\mathrm{CH}_{2} \mathrm{Cl}_{2}\right), e e=98.7 \%$ by GC, IR (film, $\left.\mathrm{cm}^{-1}\right): v 3421,2933,2857,1620,1479,1448,1234,1151,1067,1031,949,792,714$. 


\section{Acknowledgements}

This project was supported by the New Széchenyi Development Plan ("Development of quality-oriented and harmonized $R+D+I$ strategy and functional model at BME" project, TÁMOP-4.2.1/B-09/1/KMR-2010-0002). PF thanks the scholarship from Pro Progressio

Foundation (Budapest, Hungary). Thanks are also due to ThalesNano Nanotechnology Inc. for the fillable CatCart ${ }^{\mathrm{TM}}$ columns and to Prof. Mihály Nógrádi (Budapest, Hungary) for his valuable comments.

\section{References}

1. Barden T. C. Indoles: Industrial, Agricultural and Over-the-Counter Uses. In Heterocyclic Scaffods II (Topics in Heterocyclic Chemistry, Vol 26); Gribble, G. W., Ed.; Springer-Verlag, Berlin Heidelberg, 2010. 31-46.

2. Kaushik, N. K.; Kaushik, N.; Attri, P.; Kumar, N.; Kim, C. H.; Verma, A. K.; Choi, E. H. Chem. Commun, 2011, 47, 3625-3627.

3. Berger, M; Gray, J. A.; Roth, B. L. Annu. Rev. Med. 2009, 60, 355-366.

4. Phillipson, O. T. Neurobiol. Aging. 2014, 35, 847-857.

5. Borroto-Escuela, D. O.; Romero-Fernandez, W.; Narvaez, M.; Oflijan, J.; Agnati, L. F.; Fuxe, K. Biochem. Biophys. Res. Commun. 2014, 443, 278-284.

6. Chilton, W. S.; Bigwood, J.; Gensen, R. E. J. Psychedelic Drugs, 1979, 11, 61-69.

7. Jaishree, B.; Manjulatha, K.; Girish, M.; Adil, S.; Purohit, M. G. Arkivoc, 2009, 12, 217-231.

8. Murphy, J. A.; Scott, K. A.; Sinclair, R. S.; Lewis, N. Tetrahedron Lett. 1997, 38, 7295-7298.

9. Bonollo, S.; Lanari, D.; Vaccaro, L. Eur. J. Org. Chem. 2011, 14, 2587-2598.

10. Smith, J. G. Synthesis, 1984, 8, 629-656.

11. Cooper, G.; Irwin, W. J. J. Chem. Soc., Perkin Trans. 1, 1976, 5, 545-549.

12. Kotsuki, H.; Hayashida, K.; Shimanouchi, T.; Nishizawa, H. J. Org. Chem. 1996, 61, 984-990.

13. Glas, H.; Thiel, W. R. Tetrahedron Lett. 1998, 39, 5509-5510.

14. Desai, H.; D’Souza, B. R.; Foether, D.; Johnson, B. F.; Lindsay, H. A. Synthesis, 2007, 6, 902-910.

15. Porcar, R.; Sans, V.; Ríos-Lombardía, N.; Gotor-Fernández, V.; Gotor, V.; Burguete, M. I.; GarcíaVerdugo, E.; Luis, S. V. ACS Catal. 2012, 2, 1976-1983.

16. Poppe, L.; Novák, L. Selective Biocatalysis: A Synthetic Approach, Wiley-VCH, Weinheim, 1992.

17. Liese, A.; Seelbach, K.; Wandrey, C. (Eds.), Industrial Biotransformations, 2nd ed. Wiley-VCH, Weinheim, 2006.

18. Faber, K. Biotransformations in Organic Chemistry, 6th ed. Springer, Berlin-Heilderberg, 2011.

19. Boros, Z.; Hornyánszky, G.; Nagy, J.; Poppe, L.: Stereoselective hydrolase-catalyzed processes in continuous-flow mode. In Cascade Biocatalysis: Stereoselective and Environmentally Friendly Reactions; Riva, S.; Fessner, W. Eds.; Wiley-VCH, Weinheim, 2014 (in press).

20. Bornscheuer, U. T.; Kazlauskas, R. J. Hydrolases in OrganicSynthesis: Regio- and Stereoselective Biotransformations, Wiley-VCH: Weinheim-New York, 2006.

21. Schmid, A.; Dordick, J. S.; Hauer, B.; Kiener, A.; Wubbolts, M.; Witholt, B. Nature, 2001, 409, 258268.

22. Whittal, J.; Sutton, P. (Eds.), Practical Methods for Biocatalysis and Biotransformations, John Wiley \& Sons, Ltd., Chichester, 2010.

23. Dunn, P. J.; Wells, A. S.; Williams M. T. (Eds.), Green Chemistry in the Pharmaceutical Industry, Wiley-VCH, Weinheim, 2010.

24. Busto, E.; Gotor-Fernández, V.; Gotor, V. Chem. Soc. Rev. 2010, 39, 4504-4523.

25. Humble, M. S.; Berglund, P. Eur. J. Org. Chem. 2011, 3391-3401.

26. Zhou, Z.; Hartmann, M. Top. Catal. 2012, 55, 1081-1100.

27. Ghanem, A.; Aboul-Enein, H. Y. Chirality, 2005, 17, 1-15.

28. Ghisalba, O.; Meyer, H. P.; Wohlgemuth, R. "Industrial biotransformations" in Encyclopedia of Industrial Biotechnology: Bioprocess, Bioseparation, and Cell Technology, Flickinger, M. C., (Ed.), John Wiley \& Sons, Hoboken, 2010. 
29. Hoyos, P.; Pace. V.; Alcántara, A. R. Adv. Synth. Catal. 2012, 354, 2585-2611.

30. Turner, N. J.; Curr. Opin. Chem. Biol. 2004, 8, 114-119.

31. Clouthier, M.; Pelletier, J. N. Chem. Soc. Rev. 2012, 41, 1585-1605.

32. van Rantwijk, F.; Sheldon, R. A.; Tetrahedron, 2004, 60, 501-519.

33. Garcia-Urdiales, E.; Alfonso, I.; Gotor, V. Chem. Rev. 2005, 105, 313-354.

34. Sun, J. H.; Dai, R. J.; Meng, W. W.; Deng, Y. L. Catal. Commun. 2010, 11, 987-991.

35. Poulhès, F.; Vanthuyne, N.; Bertrand, M. P.; Gastaldi, S.; Gil, G. J. Org. Chem. 2011, 76, 7281-7286.

36. Brem, J.; Bencze, L. C.; Liljeblad, A.; Turcu, M. C.; Paizs, C.; Irimie, F. D.; Kanerva, L. T. Eur. J. Org Chem. 2012, 17, 3288-3294.

37. De Miranda, A. S.; Gomes, J. C.; Rodrigues Jr, M. T.; Costa, I. C. R.; Almeida, W. P.; de O. Lopes, R.; Miranda, L. S. M.; Coelho, F.; de Souza, R. O. M. A. J. Mol. Catal. B: Enzym. 2013, 91, 77-80.

38. Boros, Z.; Falus, P.; Márkus, M.; Weiser, D.; Oláh, M.; Hornyánszky, G.; Nagy, J.; Poppe, L. J. Mol. Catal. B: Enzym. 2013, 85-86, 119-125.

39. Rouhi A. M. Chem. Eng. News. 2004, 82, 49-58.

40. Jas, G.; Kirschning, A. Chem. Eur. J. 2003, 9, 5708-5723.

41. Ceylan, S.; Kirschning, A. In: Recoverable and Recyclable Catalysts, Benaglia, M. (Ed.), pp. 379-410. John Wiley \& Sons, Ltd., New York, 2009.

42. Mak, X. Y.; Laurino, P.; Seeberger, P. H. Beilstein J. Org. Chem. 2009, 5, No. 19.

43. Rasheed, M.; Elmore, S. C.; Wirth, T. In: Catalytic methods in asymmetric synthesis - Advanced materials, techniques, and applications, Gruttadauria, M.; Giacalone, F. (Eds.), pp. 345-372. John Wiley \& Sons, Inc., Hoboken, 2011.

44. Yuryev, R.; Strompen, S.; Liese, A. Beilstein J. Org. Chem. 2011, 7, 1449-1467.

45. Microreactors in Organic Synthesis, 2nd Ed, Wirth, T. (Ed.), Wiley-VCH, Weinheim, 2013.

46. Sheldon, R. A. Adv. Synth. Catal. 2007, 349, 1289-1307.

47. Mateo, C.; Palomo, J. M.; Fernandez-Lorente, G.; Guisan, J. M.; Fernandez-Lafuente, R. Enzyme Microb. Technol. 2007, 40, 1451-1463.

48. Hanefeld, U.; Gardossi, L.; Magner, E., Chem. Soc. Rev. 2009, 38, 453-468.

49. Garcia-Galan, C., Berenguer-Murcia, A.; Fernandez-Lafuente, R.; Rodrigues, R. C. Adv. Synth. Catal. 2011, 353, 2885-2904.

50. Sheldon, R. A.; van Pelt, S. Chem. Soc. Rev. 2013, 42, 6223-6235.

51. Rodrigues, R. C.; Ortiz, C.; Berenguer-Murcia, A.; Torres, R.; Fernández-Lafuente, R. Chem. Soc. Rev. 2013, 42, 6290-6307.

52. Lam, L. K. P.; Hui, R. A.; Jones, J. B. J. Org. Chem. 1986, 51, 2047-2050.

53. Rantakylä, M.; Aaltonen, O. Biotechnol. Lett. 1994, 16, 825-830.

54. Molinari, F.; Mantegazza, L.; Villa, R.; Aragozzini, F. J. Ferment. Bioeng. 1998, 86, $62-64$.

55. Ljubović, E.; Majerić-Elenkov, M.; Avgadić, A.; Šunjić, V. Food Technol. Biotechnol. 1999, 37, 215224.

56. López-Serrano, P.; Wegman, M. A.; van Rantwijk, F.; Sheldon, R. A. Tetrahedron Asymmetry, 2001, 12, 235-240.

57. Cainelli, G.; Galletti, P.; Giacomini, D.; Gualandi, A.; Quintavalla, A. Helv. Chim. Acta, 2003, 86, 3548-3559.

58. Sakai, T. Tetrahedron: Asymmetry, 2004, 15, 2749-2756.

59. Moon-Young, Y.; Lee, S. H.; Cheong, C. S.; Park, J. K. Enzyme Microb. Technol. 2004, 35, 574-580.

60. Chen, C. C.; Tsai, S. W.; Enzyme Microb. Technol. 2005, 36, 127-132.

61. Lin, C.; Hiraga, Y.; Masaki, K.; Iefuji, H.; Ohkata, K. Biocatal. Biotransform. 2006, 24, 390-395.

62. Yang, G.; Wu, J.; Xu, G.; Yang, L. Appl. Microbiol. Biotechnol. 2009, 81, 847-853.

63. Cipiciani, A.; Bellezza, F.; Fringuelli, F.; Silvestrini, M. G. Tetrahedron: Asymmetry, 2001, 12, 22772281.

64. Magnusson, A. O.; Takwa, M.; Hamberg, A.; Hult, K. Angew. Chem. Int. Ed. 2005, 44, 4582-4585.

65. Csajági, C.; Szatzker, G.; Tőke, E. R.; Ürge, L.; Darvas, F.; Poppe, L. Tetrahedron: Asymmetry, 2008, 19, 237-246.

66. Barton, M. J.; Hamman, J. P.; Fichter, K. C.; Calton, G. J. Enzyme Microb. Technol. 1990, 12, $577-583$.

67. Gharpure, S. J.; Sathiyanarayanan, A. M. Chem. Commun. 2011, 47, 3625-3627.

68. Chen, C. S.; Fujimoto, Y.; Girdaukas, G.; Sih, C. J. J. Am. Chem. Soc. 1982, 104, 7294-7299.

69. Boros, Z.; Abaháziová, E.; Oláh, M.; Sátorhelyi, P.; Erdélyi, B.; Poppe, L. Chim. Oggi, 2012, 30, 2629.

70. Choi, E.; Kim, Y.; Ahn, Y.; Park, J.; Kim, M. Tetrahedron: Asymmetry, 2013, 24, 1449-1452. 


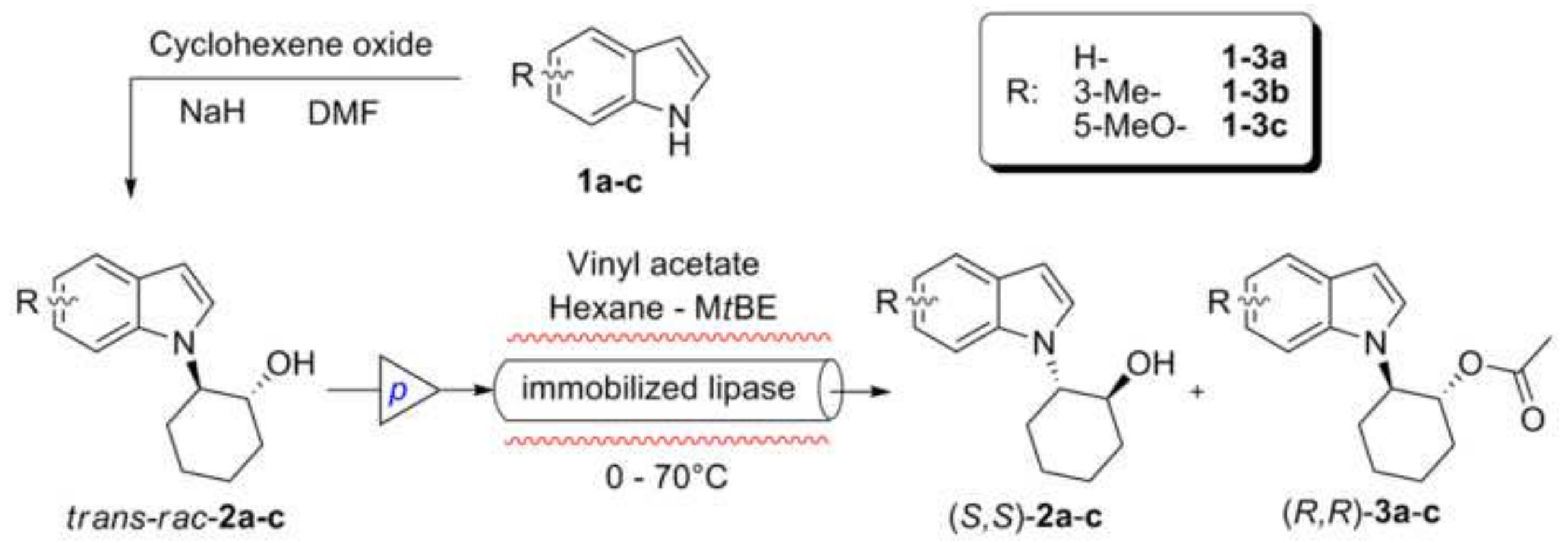




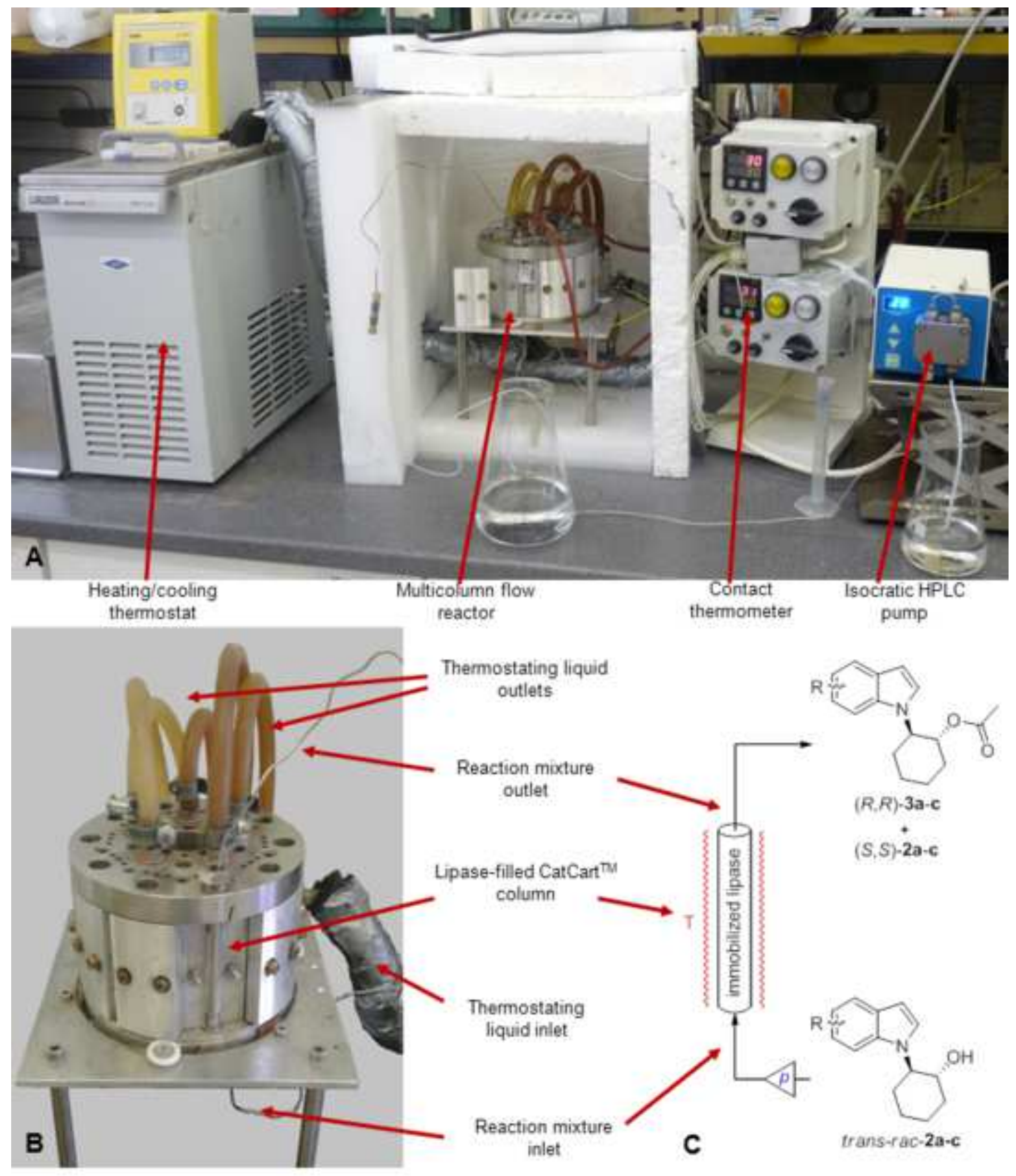




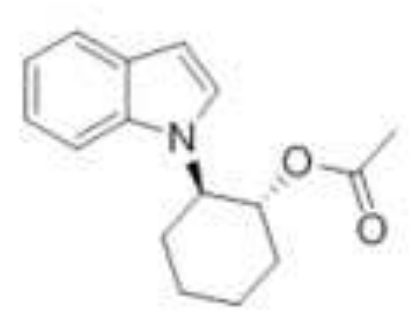

$(R, R)-3$ a

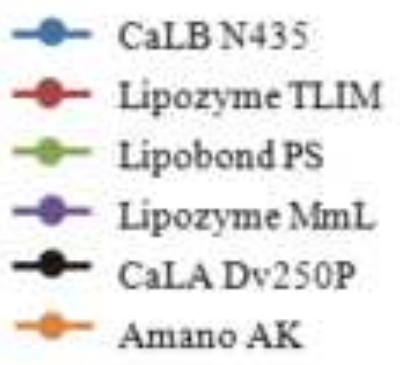

Amano AK
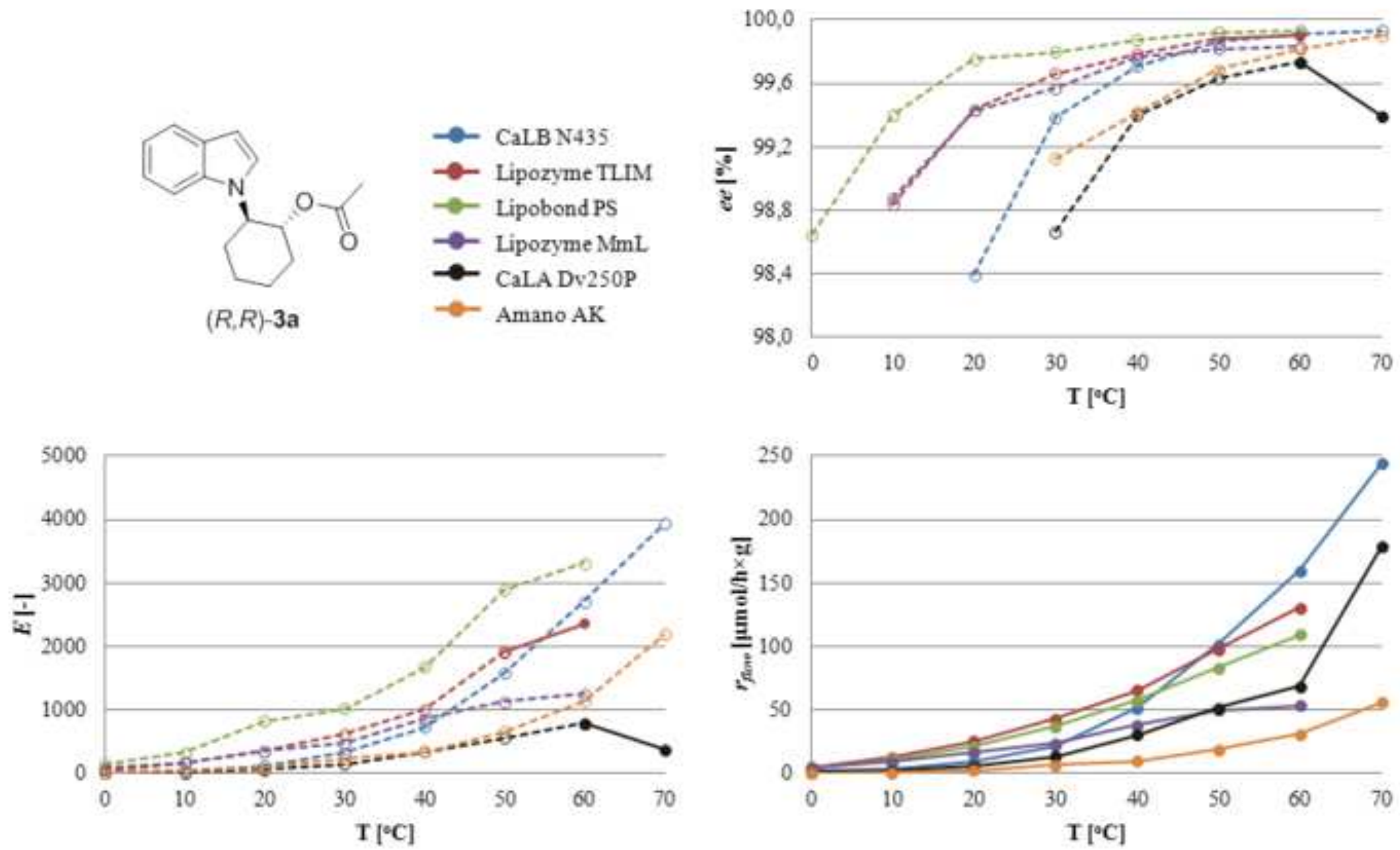


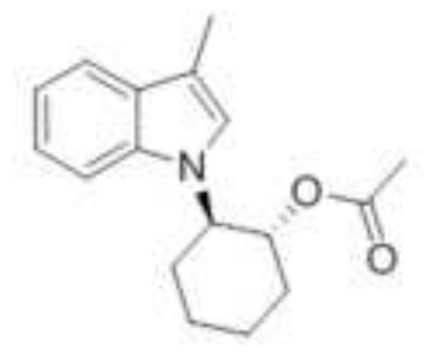

(R,R)-3b
- CaLBN435

$\rightarrow$ Lipozyme TLIM

- Lipobond PS

-6 Lipozyme MmL

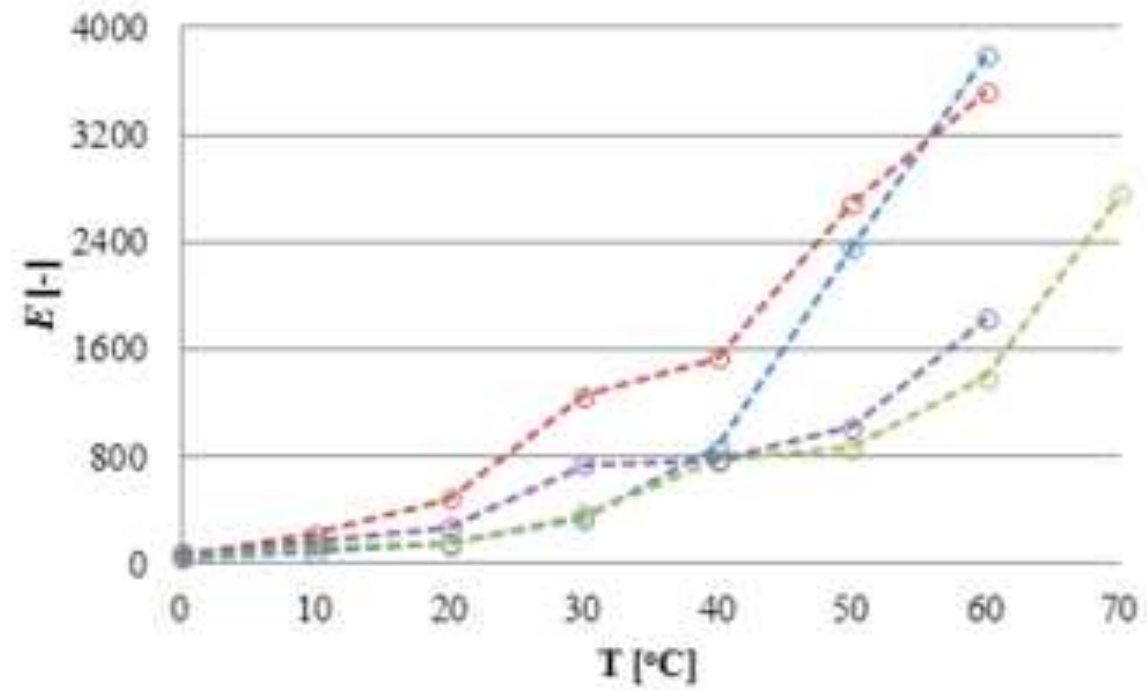

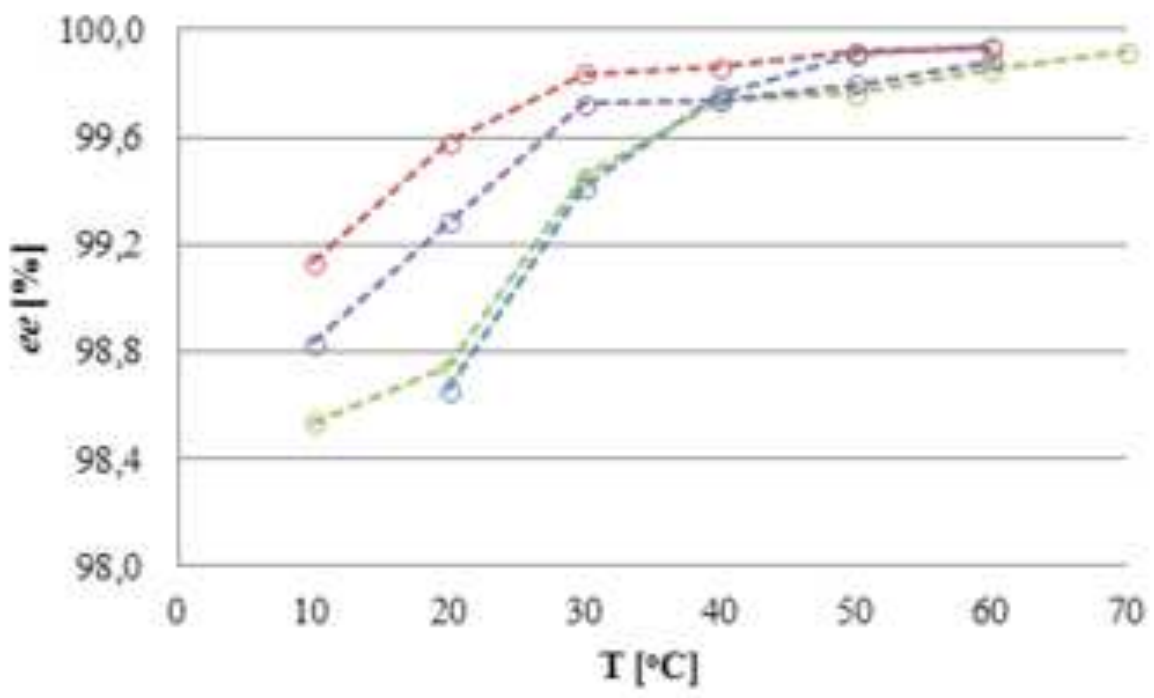

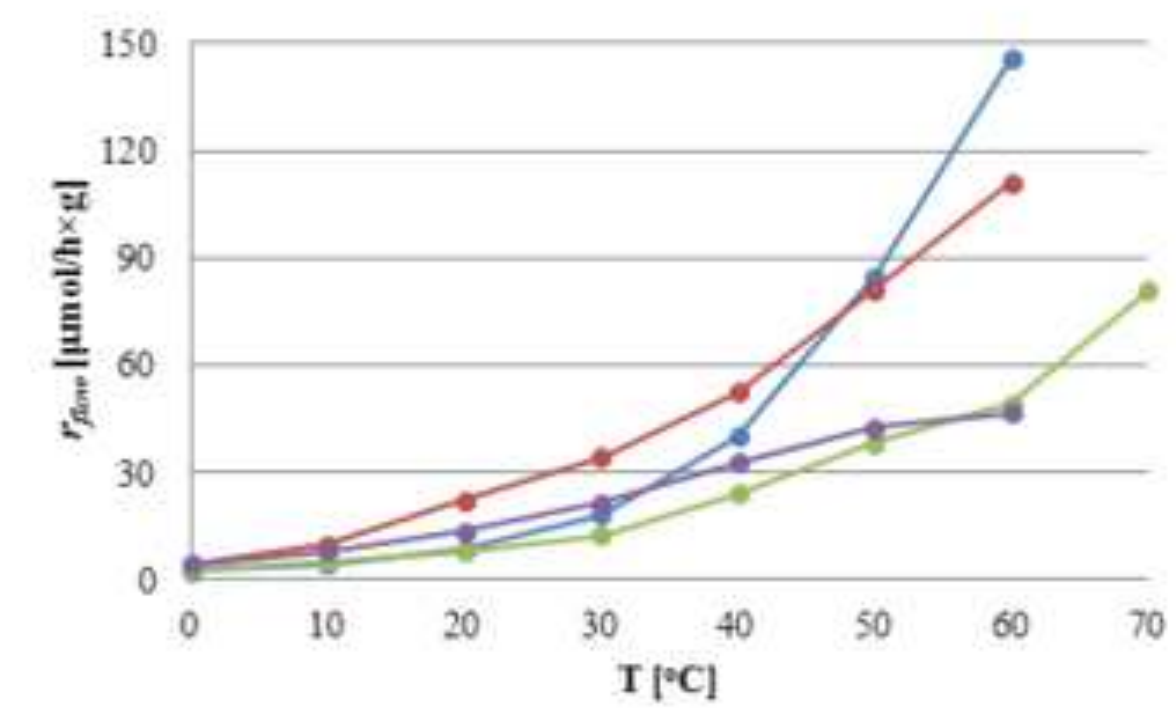




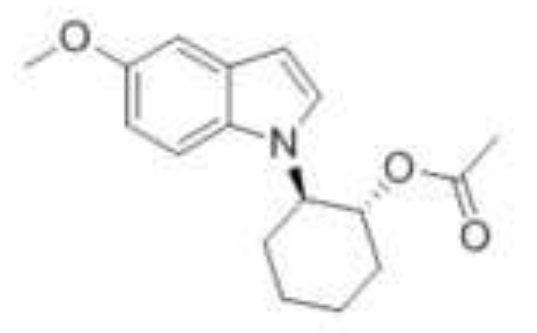

$(R, R)-3 \mathrm{c}$

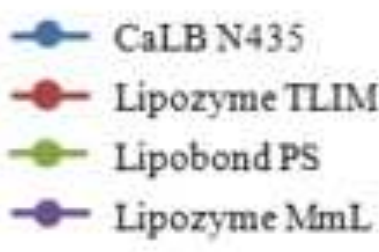

Lipozyme MmL
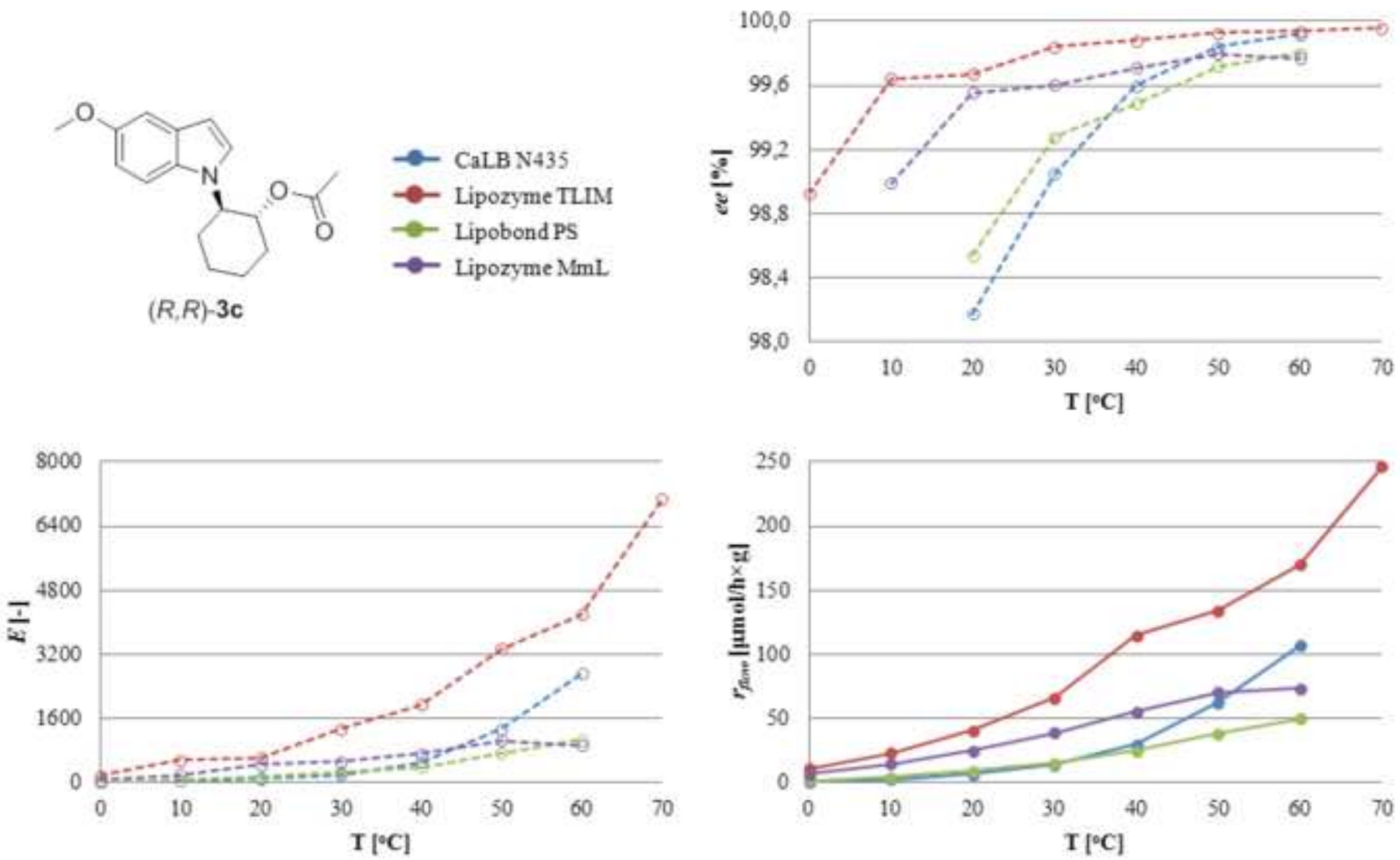

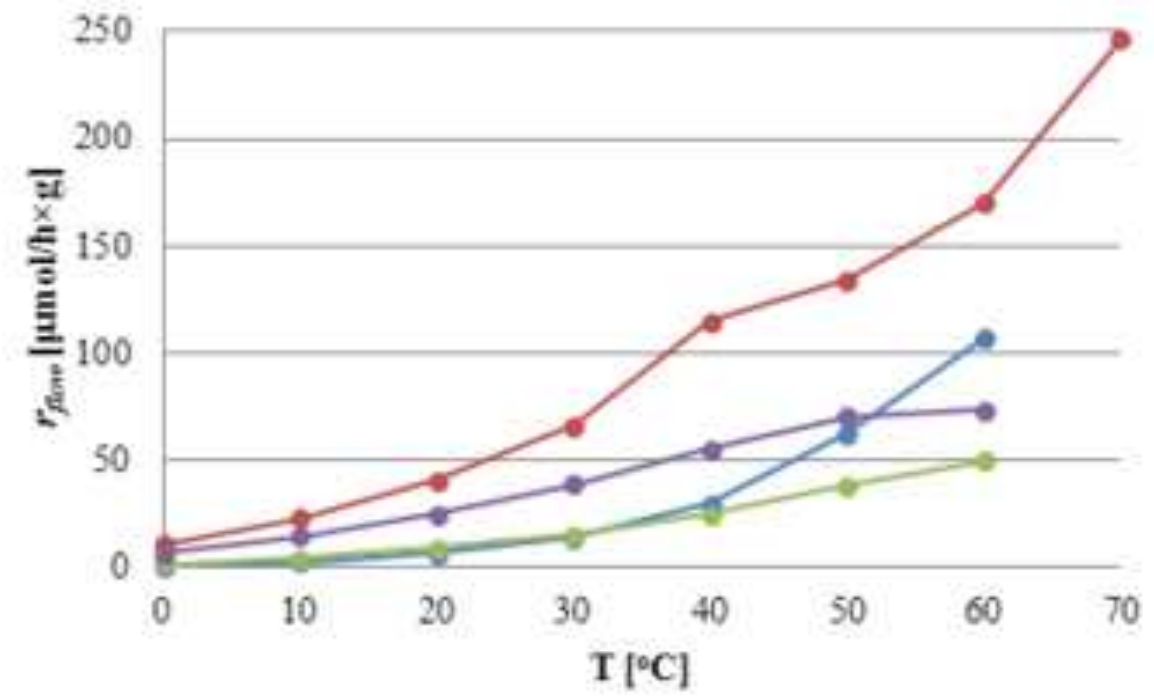




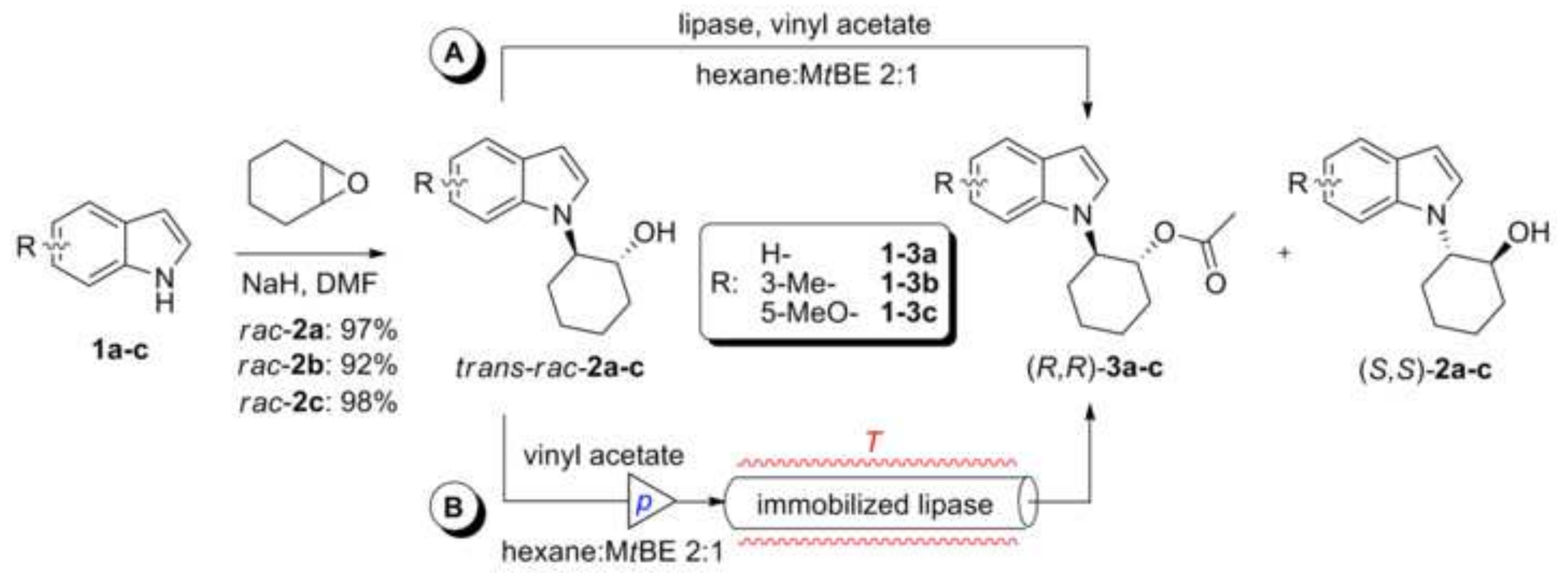


Table 1. Lipase-catalysed kinetic resolution of secondary alcohols ( $r a c-2 a-c)$ by acylation with vinyl acetate in batch mode $\left(30^{\circ} \mathrm{C}\right.$, shake flask).

\begin{tabular}{|c|c|c|c|c|c|c|}
\hline Entry & Substrate & Enzyme & $c(\%)^{a}$ & $e e_{(R, R)-\mathbf{3} \mathbf{a}}(\%)^{b}$ & $E^{c}$ & 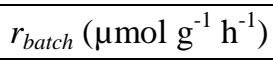 \\
\hline \multicolumn{7}{|c|}{ Panel $\mathrm{A}^{d}$} \\
\hline 1 & $r a c-\mathbf{2 a}$ & CaLB N435 & 49.9 & $>99.9$ & $» 200$ & 32.6 \\
\hline 2 & $r a c-\mathbf{2 a}$ & Lipobond PS & 47.2 & >99.9 & $\gg 200$ & 30.8 \\
\hline 3 & $r a c-\mathbf{2 a}$ & Lipozyme TLIM & 40.2 & >99.9 & $\gg 200$ & 26.2 \\
\hline 4 & $r a c-\mathbf{2 a}$ & Lipozyme MmL & 38.7 & >99.9 & $\gg 200$ & 25.3 \\
\hline 5 & $r a c-\mathbf{2 a}$ & Amano AK & 37.0 & $>99.9$ & $\gg 200$ & 24.1 \\
\hline 6 & $r a c-\mathbf{2 a}$ & CaLA G250P & 25.1 & 99.8 & $\gg 200$ & 16.4 \\
\hline 7 & $r a c-\mathbf{2 a}$ & CaLA T2-150 & 14.7 & 99.6 & $» 200$ & 9.6 \\
\hline 8 & $r a c-\mathbf{2 a}$ & MpL G250P & 13.9 & 99.9 & $\gg 200$ & 9.0 \\
\hline 9 & $r a c-\mathbf{2 a}$ & MpL G250O & 11.1 & 99.9 & $» 200$ & 7.2 \\
\hline 10 & $r a c-\mathbf{2 a}$ & CaLB G250P & 9.4 & 99.9 & $\gg 200$ & 6.2 \\
\hline 11 & $r a c-\mathbf{2 a}$ & PaL G250P & 8.6 & 99.8 & $» 200$ & 5.6 \\
\hline \multicolumn{7}{|c|}{ Panel B ${ }^{e}$} \\
\hline 12 & $r a c-\mathbf{2 b}$ & CaLB N435 & 41.2 & >99.9 & $\gg 200$ & 37.6 \\
\hline 13 & $r a c-\mathbf{2 b}$ & Lipobond PS & 27.7 & >99.9 & $\gg 200$ & 25.0 \\
\hline 14 & $r a c-\mathbf{2 b}$ & Lipozyme TLIM & 27.4 & $>99.9$ & $» 200$ & 25.0 \\
\hline 15 & $r a c-\mathbf{2 b}$ & Lipozyme MmL & 24.1 & >99.9 & $\gg 200$ & 21.7 \\
\hline 16 & $r a c-\mathbf{2 b}$ & CaLB G250P & 12.9 & 99.9 & $\gg 200$ & 11.9 \\
\hline 17 & $r a c-\mathbf{2 b}$ & Amano AK & 9.0 & 99.9 & $\gg 200$ & 8.1 \\
\hline 18 & $r a c-\mathbf{2 b}$ & Amano M & 6.5 & 99.9 & $» 200$ & 5.9 \\
\hline 19 & $r a c-\mathbf{2 b}$ & Amano PS & 5.5 & 99.8 & $» 200$ & 5.0 \\
\hline \multicolumn{7}{|c|}{ Panel $C^{e}$} \\
\hline 20 & $r a c-\mathbf{2 c}$ & Lipozyme TLIM & 44.9 & >99.9 & $» 200$ & 38.6 \\
\hline 21 & $r a c-\mathbf{2 c}$ & CaLB N435 & 38.7 & >99.9 & $\gg 200$ & 33.0 \\
\hline 22 & $r a c-\mathbf{2 c}$ & Lipozyme MmL & 34.4 & >99.9 & $\gg 200$ & 29.1 \\
\hline 23 & $r a c-\mathbf{2 c}$ & Lipobond PS & 33.5 & >99.9 & $\gg 200$ & 28.5 \\
\hline 24 & $r a c-\mathbf{2 c}$ & Amano AK & 27.0 & 99.9 & $» 200$ & 22.8 \\
\hline 25 & $r a c-\mathbf{2 c}$ & CaLB G250P & 13.7 & 99.9 & $» 200$ & 11.7 \\
\hline 26 & $r a c-\mathbf{2 c}$ & CaLA G250P & 10.6 & 99.9 & $\gg 200$ & 9.0 \\
\hline 27 & $r a c-\mathbf{2 c}$ & $\mathrm{CrL}$ & 7.3 & 99.9 & $» 200$ & 6.2 \\
\hline 28 & $r a c-\mathbf{2 c}$ & Amano PS & 7.2 & 99.8 & $» 200$ & 6.1 \\
\hline 29 & $r a c-2 c$ & CaLA T2-150 & 6.9 & 99.8 & $\gg 200$ & 5.9 \\
\hline
\end{tabular}

${ }^{a}$ Results are shown only for reactions with $c>5 \%$.

${ }^{b}$ Enantiomeric excess of ester $\left(e e_{(R, R)-3 \mathrm{a}-\mathrm{c}}\right)$ was determined by chiral GC.

${ }^{c}$ Enantiomeric ratio $(E)$ was calculated from $c$ and $e e_{(R, R)-3 a-c} \cdot{ }^{68}$ For simplicity, $E$ values calculated above 500 were given as $\gg 200$.

${ }^{d}$ Reaction time $72 \mathrm{~h}$.

${ }^{e}$ Reaction time $48 \mathrm{~h}$.

\footnotetext{
${ }^{68}$ Chen, C. S.; Fujimoto, Y.; Girdaukas, G.; Sih, C. J. J. Am. Chem. Soc. 1982, 104, 7294-7299.
} 
Table 2. Alcohols prepared by kinetic resolution of $\mathrm{rac}-\mathbf{2 a - \mathbf { c }}$ with vinyl acetate in a CaLB N435-filled continuous-flow reactor at preparative scale followed by Zemplén deacylation of the formed $(R, R)-3 \mathbf{a}-\mathbf{c}$.

\begin{tabular}{lccc}
\hline Compound & Yield $(\%)$ & $e e(\%)^{a}$ & {$[\alpha]_{D}^{26^{\circ} \mathrm{Cb}}$} \\
\hline$(R, R)-\mathbf{2 a}$ & $36^{c}$ & 97.8 & +0.86 \\
$(S, S)-\mathbf{2 a}$ & 39 & 87.9 & -0.75 \\
$(R, R)-\mathbf{2 b}$ & $33^{c}$ & 98.1 & +0.17 \\
$(S, S)-\mathbf{2 b}$ & 34 & 94.8 & -0.07 \\
$(R, R)-\mathbf{2 c}$ & $35^{c}$ & 98.7 & +0.47 \\
$(S, S)-\mathbf{2}$ & 33 & 93.1 & -0.19 \\
$(R, R)-3 \mathbf{a}$ & 45 & 99.1 & +12.7 \\
$(R, R)-\mathbf{3 b}$ & 43 & 99.5 & +10.7 \\
$(R, R)-3 \mathbf{c}$ & 42 & 99.2 & +11.8 \\
\hline
\end{tabular}

\footnotetext{
${ }^{a}$ Enantiomeric excess was determined by chiral GC (see Section 4.2).

${ }^{b}$ Specific rotations, $\left(c 1.0, \mathrm{CH}_{2} \mathrm{Cl}_{2}\right)$.

${ }^{c}$ Combined yield of kinetic resolution and Zemplén deacylation.
} 